University of Chicago Law School

Chicago Unbound

Journal Articles

Faculty Scholarship

2002

\title{
The Principle and Practice of Women's 'Full Citizenship': A Case Study of Sex-Segregated Public Education
}

Jill Elaine Hasday

Follow this and additional works at: https://chicagounbound.uchicago.edu/journal_articles

Part of the Law Commons

\section{Recommended Citation}

Jill Elaine Hasday, "The Principle and Practice of Women's 'Full Citizenship': A Case Study of SexSegregated Public Education," 101 Michigan Law Review 755 (2002).

This Article is brought to you for free and open access by the Faculty Scholarship at Chicago Unbound. It has been accepted for inclusion in Journal Articles by an authorized administrator of Chicago Unbound. For more information, please contact unbound@law.uchicago.edu. 


\title{
THE PRINCIPLE AND PRACTICE OF WOMEN'S "FULL CITIZENSHIP": A CASE STUDY OF SEX-SEGREGATED PUBLIC EDUCATION
}

\author{
Jill Elaine Hasday*
}

INTRODUCTION 756

I. HEIGHTENED SCRUTINY, "Full CITIZENSHIP STATURE," AND "LEGAL, SOCIAL, AND ECONOMIC INFERIORITY"

A. The Uncertain Reach and Reasoning of Heightened Scrutiny

B. "Full Citizenship Stature" and "Legal, Social, and Economic Inferiority" 769

II. SEX-Segregated Public EduCATION: A CASE Study IN USING HISTORY TO INFORM AN INQUIRY INTO WHETHER A SPECIFIC PRACTICE DENIES WOMEN "FULL CITIZENSHIP STATURE" OR MAINTAINS THEIR "LEGAL, SOCIAL, AND ECONOMIC INFERIORITY".

A. Different Populations of Women Are Not Necessarily Interchangeable in Considering What Denies Women "Full Citizenship" and Maintains Their "Inferiority"

B. Separation Is Not the Only Mechanism for Denying Women "Full Citizenship" and Maintaining Their "Inferiority": The Historical Overlap Between SexSegregated and Coeducational Public Education 792

C. Women and Men Are Not Necessarily Interchangeable in Considering What Denies "Full Citizenship" and Maintains "Inferiority"

* Associate Professor, University of Chicago Law School. B.A. 1994, J.D. 1997, Yale. - Ed. I would like to thank Jack Balkin, Emily Buss, Mary Anne Case, Adrienne Davis, Ariela Dubler, Allan Erbsen, Elizabeth Garrett, Robert Hasday, Saul Levmore, Tracey Meares, Eric Posner, Reva Siegel, Cass Sunstein, Adrian Vermeule, and the participants in faculty workshops at the University of Chicago Law School, the Emory University School of Law, the Feminism and Legal Theory Project Conference on Gender and Citizenship at Cornell Law School, the University of Texas School of Law Conference on Subversive Legacies: Learning from History/Constructing the Future, the fifth annual meeting of the Association for the Study of Law, Culture and the Humanities, and the joint meetings of the Canadian Law and Society Association and the Law and Society Association. Rachel Bennett, Bryan Dayton, John Fitzgerald, Tamara Killion, and the University of Chicago Law Library provided excellent research assistance. The Insurance Research Fund and the Lee and Brena Freeman Faculty Research Fund contributed generous financial support. $\odot$ 2002, Jill Elaine Hasday. 


\section{INTRODUCTION}

For more than a quarter century, the Supreme Court has repeatedly declared that sex-based state action is subject to heightened scrutiny under the Equal Protection Clause. But the Court has always been much less clear about what that standard allows and what it prohibits. For this reason, it is especially noteworthy that one of the Court's most recent sex discrimination opinions, United States $v$. Virginia,' purports to provide more coherent guidance.

Virginia suggests that the constitutionality of sex-based state action turns on whether the practice at issue denies women "full citizenship stature" or "create[s] or perpetuate[s] the legal, social, and economic inferiority of women."2 Yet the opinion does not begin to indicate how the sex discrimination jurisprudence might implement this new standard. In particular, it does not tell us how to determine whether any specific practice deprives women of "full citizenship" or maintains their "inferiority."

The answer to this question is far from obvious. Indeed, even the large legal literature that has long argued that constitutional law enforcing the Equal Protection Clause should be structured around a commitment to combating "subordination" provides us with relatively little guidance. This literature would seem to have concerns importantly aligned to those that Virginia articulates. But it ultimately does not teach us much about how to identify the practices that undermine women's "full citizenship" or sustain their "inferiority."

This Article attempts to give some content to the framework that Virginia presents. More specifically, it explores how analyzing the historical record of a practice can inform an investigation into whether, when, and why that practice is consistent with women's "full citizenship stature" or operates to perpetuate their "legal, social, and economic inferiority." $"$

History is not the only source that one could use in considering how to give flesh to the standard that Virginia suggests, and the social understandings and distributive consequences associated with a practice over time cannot conclusively establish how a practice is currently functioning or should currently be regulated. But examining a practice at some remove from the present can reveal hidden dimensions of a problem and bring into sharper focus questions that are obscured in contemporary debates. A historical record can direct a Court's atten-

1. 518 U.S. 515 (1996).

2. Id. at 532,534 .

3. $I d$.

4. Id.

5. Id. 
tion toward particular issues, uncover areas of concern, and illuminate factors that might be relevant. This Article takes the historical record of sex-segregated public education in the United States as its case study. That record is an especially apt place to begin because Virginia directly concerned the constitutional status of a sex-segregated public school. ${ }^{6}$

The Article proceeds in two parts. The first examines heightened scrutiny, "full citizenship stature," and "legal, social, and economic inferiority" as they appear and function in the Court's sex discrimination jurisprudence. ${ }^{7}$ The second considers how the historical record of sexsegregated public education might help us learn what we would need to know in order to determine whether, when, and why the practice of sex-segregated public education denies women "full citizenship stature" or "create[s] or perpetuate[s] the legal, social, and economic inferiority of women."

As we will discover, the record of sex-segregated public education over time suggests that Virginia's "full citizenship" standard may ultimately challenge many of the assumptions on which the current sex discrimination jurisprudence is based, including some endorsed in Virginia itself. ${ }^{9}$ For example, Virginia, like the sex discrimination case law before it, appears to treat the claims of different populations of women as constitutionally interchangeable. But the historical record of sex-segregated public education reveals that practices can deny "full citizenship" to one set of women and not another, or can deprive different groups of women of "full citizenship" in different ways. ${ }^{10}$ The practice of sex-segregated public education, for instance, has historically been entangled in both racial and class stratification, and has inflicted injuries on women that varied depending on their racial and economic status. This suggests that a decisionmaker regulating singlesex public schools under the framework Virginia outlines would be well-advised to consider whether some or all of those schools have different consequences for different groups of women.

Similarly, the current sex discrimination jurisprudence focuses on separation as the mechanism through which inequality is maintained, perhaps because this mechanism has featured so prominently in the history of race discrimination in the United States. The sex discrimination case law seems to assume, for example, that sex-segregated and coeducational public education are wholly different practices, directing constitutional scrutiny at the former while all but ignoring the pos-
6. See id. at 519.
7. Id. at 532,534 .
8. Id.
9. Id. at 532 .
10. Id. 
sibility that coeducational public schools might operate to undermine women's equal citizenship.

Yet the historical record of sex-segregated (and coeducational) public education makes clear that separation of the sexes is not the only means by which practices can deprive women of "full citizenship" and sustain their "inferiority." Some of the same mechanisms of inferiority can function in both sex-segregated and coeducational public schools. Indeed, the historical record reveals that differences of form like that between sex-segregated and coeducational public education can actually prove relatively unimportant in terms of their substantive impact on women's status. Through at least the first half of the twentieth century, for instance, sex-segregated public education was systematically structured to steer and push women toward marriage and motherhood and to discourage and disable them from pursuing prominent participation in economic or political affairs. This feature of the practice, which we might call "sex role confinement," did not depend on separation, however. Role confinement was present in approximately equal measure in the coeducational public schools of the period.

This suggests that a Court considering whether all sex-segregated public education should be constitutionally prohibited under Virginia's framework-a question that the Court has yet to decide-could usefully compare the practices of sex-segregated and coeducational public education. Presumably, a Court would be unwilling to categorically ban coeducational public schooling. But if the practices of sexsegregated and coeducational public education turn out to be operating with equal effect to maintain women's "legal, social, and economic inferiority," it is hard to see why a jurisprudence committed to women's "full citizenship" would want to emphasize form by absolutely prohibiting sex-segregated public schooling, or how transferring all public school students to coeducational schools would advance women's "full citizenship stature" and fight their "inferiority." 12 Along the same lines, this record also suggests that if sex-segregated public education is not absolutely prohibited under Virginia's framework, a Court determining what constitutional regulations would best prevent single-sex public schools from undermining women's equal citizenship should consider the potential problem of role confinement. Similarly, a Court interested in protecting women's equal status would be wise to focus much more constitutional scrutiny on coeducational public schools directly, examining them also as possible sources of women's inequality.

11. Id. at 532,534 .

12. Id. 
Finally, the Virginia opinion appears to express a particular constitutional interest in women's "full citizenship stature" and "the legal, social, and economic inferiority of women." ${ }^{\text {"3 }}$ But prior sex discrimination cases, and parts of Virginia, treat men and women interchangeably. For instance, all of the Court's opinions on sex-segregated public education are committed to the proposition that single-sex public schools - whether they enroll male or female students-must conform to separate but equal standards by not excluding a sex of students that lacks access to equal public educational opportunities elsewhere in the jurisdiction. The historical record of sex-segregated public education, however, reveals that a practice that functions to deprive women of "full citizenship" may not necessarily inflict the same harms on men. ${ }^{14}$ For example, women's exclusion from men's public schools, when women did not have the same opportunities available elsewhere, has often caused women to suffer serious dignitary and material harm. But it is not at all clear that men's exclusion from women's public schools (when they did not have same opportunities available elsewhere) has historically operated to impinge upon the "full citizenship" of either men or women. ${ }^{15}$ This suggests that separate but equal standards may not always be needed to prevent sex-segregated public schools from denying equal citizenship, although the Court may remain committed to those standards as a required constitutional minimum for other reasons. More-generally, it suggests that a Court applying Virginia's framework could usefully consider the possibility that a practice may have a different effect and meaning for women and men.

Before we explore the potential uses of history in more detail, however, let's begin by examining the current, uneasy state of the constitutional law of sex discrimination.

\section{HEIGHTENED SCRUTINY, "Full CitIZENSHIP STATURE," AND "LEGAL, SOCIAL, AND ECONOMIC INFERIORITY"}

\section{A. The Uncertain Reach and Reasoning of Heightened Scrutiny}

In 1976, the Supreme Court determined that sex-based state action would be subject to heightened scrutiny under the Equal Protection Clause of the Fourteenth Amendment, meaning that it would be held unconstitutional unless it served "important governmental objectives" and was "substantially related to achievement of those objectives." 16 This was an intermediate standard of constitutional review, deliber-

13. Id. (emphasis added).

14. Id. at 532.

15. Id.

16. Craig v. Boren, 429 U.S. 190, 197 (1976), 
ately situated between rational basis analysis, which almost always upholds the constitutionality of challenged actions, and strict scrutiny, which almost always strikes practices down. How heightened scrutiny would draw the line between constitutional and unconstitutional activity was, accordingly, a particularly pressing question from the start. But over the course of more than a quarter century, the sex discrimination jurisprudence has remained noticeably unclear on this issue.

The sex discrimination case law has established that its concern centers narrowly on state action that explicitly distinguishes based on sex. Facially neutral state action is subject to heightened scrutiny only if the plaintiff can prove the equivalent of legislative malice: "that the decisionmaker... selected or reaffirmed a particular course of action at least in part 'because of,' not merely 'in spite of,' its adverse effects upon" women or men. ${ }^{17}$ The Court, however, has offered much less guidance as to which forms of explicit sex-based state action violate equal protection.

One theme emphasized in the case law stresses that the constitutional claims of men and women are interchangeable. Consider, for instance, Craig v. Boren, ${ }^{18}$ the case that the Court selected for its announcement that heightened scrutiny would apply to sex-based state action. ${ }^{19}$ Craig, the foundational case in the Court's constitutional jurisprudence of sex discrimination, involved a male plaintiff rather than a woman. It addressed, moreover, an issue of little, if any, relevance to women's status in society: the right of young men to buy "'nonintoxicating' $3.2 \%$ beer" at the same age that young women could purchase it. $^{20}$

Another theme visible in the sex discrimination jurisprudence condemns what the Court calls "invidious, archaic, and overbroad stereotypes about the relative abilities of men and women,"21 "fixed notions concerning the roles and abilities of males and females," "archaic and stereotypic notions," ${ }^{23}$ or "“archaic and overbroad' generalizations." The concern here appears to be with legal practices that separate men

17. Pers. Adm'r v. Feeney, 442 U.S. 256, 279 (1979).

18. 429 U.S. at 190.

19. See id. at 197.

20. Id. at 191-92. For some additional examples of successful sex discrimination suits that featured male plaintiffs, see J.E.B. v. Alabama ex rel. T.B., 511 U.S. 127, 129 (1994); Mississippi Univ, for Women v. Hogan, 458 U.S. 718, 720, 723 (1982); Wengler v. Druggists Mut. Ins. Co., 446 U.S. 142, 143, 147 (1980); Caban v. Mohammed, 441 U.S. 380, 381-82 (1979); Orr v. Orr, 440 U.S. 268, 271 (1979); Califano v. Goldfarb, 430 U.S. 199, 202-03 (1977) (plurality opinion).

21. J.E.B., 511 U.S, at 131 .

22. Hogan, 458 U.S. at 725.

23. Id.

24. Goldfarb, 430 U.S. at 217 (quoting Schlesinger v. Ballard, 419 U.S. 498, 508 (1975)). 
and women based on beliefs about their respective abilities or preferences that are inaccurate in the sense that they do not correctly describe every man or every woman, although they may be true about most (or almost all) men or women. By repeatedly characterizing such practices as archaic-even when they accurately classify vast numbers of present-day citizens-the Court's statements suggest that these practices are completely at odds with the modern sex discrimination jurisprudence and not to be tolerated. Drawing on this theme, the Court has struck down a wide variety of sex-based legal classifications under heightened scrutiny, ${ }^{25}$ with the exceptions generally tending to cluster around sex-specific rules that the Court understands to be inseparably tied to the gestational capacity that all women (presumptively) possess. ${ }^{26}$

25. See, e.g., J.E.B., 511 U.S. at 129 (" [W]e are faced with the question whether the Equal Protection Clause forbids intentional discrimination on the basis of gender ['in the exercise of peremptory challenges'].... We hold that gender... is an unconstitutional proxy for juror competence and impartiality."); Kirchberg v. Feenstra, 450 U.S. 455, 456 (1981) (" $[\mathrm{W}] \mathrm{e}$ consider the constitutionality of a now superseded Louisiana statute that gave a husband, as 'head and master' of property jointly owned with his wife, the unilateral right to dispose of such property without his spouse's consent. [We] [c]onclud[e] that the provision violates the Equal Protection Clause of the Fourteenth Amendment ...."); Wengler, 446 U.S. at $144-46,152$ ("[Under $\$ 287.240$,] a widower is not entitled to death benefits unless he either is mentally or physically incapacitated from wage earning or proves actual dependence on his wife's earnings. In contrast, a widow qualifies for death benefits without having to prove actual dependence on her husband's earnings.... [W] conclude that the Supreme Court of Missouri erred in upholding the constitutional validity of $\$ 287.240 . "$ ); Califano v. Westcott, 443 U.S. 76, 78, 89 (1979) ("Section 407 of the Social Security Act ... provides benefits to families whose dependent children have been deprived of parental support because of the unemployment of the father, but does not provide such benefits when the mother becomes unemployed.... We conclude that the gender classification of 8 407 ... cannot survive scrutiny under the Due Process Clause of the Fifth Amendment."); Caban, 441 U.S. at 386-87, 394 ("[A]n unwed mother has the authority under New York law to block the adoption of her child simply by withholding consent. The unwed father has no similar control over the fate of his child, even when his parental relationship is substantialas in this case. He may prevent the termination of his parental rights only by showing that the best interests of the child would not permit the child's adoption by the petitioning couple.... We conclude that this undifferentiated distinction between unwed mothers and unwed fathers, applicable in all circumstances where adoption of a child of theirs is at issue, does not bear a substantial relationship to the State's asserted interests."); Orr, 440 U.S. at 270-71 ("The question presented is the constitutionality of Alabama alimony statutes which provide that husbands, but not wives, may be required to pay alimony upon divorce. . . We now hold the challenged Alabama statutes unconstitutional...."); Goldfarb, 430 U.S. at 201-02 ("Under the Federal Old-Age, Survivors, and Disability Insurance Benefits (OASDI) program, survivors' benefits based on the earnings of a deceased husband covered by the Act are payable to his widow. Such benefits on the basis of the earnings of a deceased wife covered by the Act are payable to the widower, however, only if he "was receiving at least one-half of his support' from his deceased wife.... A three-judge District Court for the Eastern District of New York held that the different treatment of men and women mandated by $\S 402(f)(1)(D)$ constituted invidious discrimination against female wage earners by affording them less protection for their surviving spouses than is provided to male employees....We affirm.") (citations omitted).

26. See, e.g., Lehr v, Robertson, 463 U.S. 248, 266-68 (1983) (upholding legislation that "guarantees to certain people the right to veto an adoption and the right to prior notice of any adoption proceeding. The mother of an illegitimate child is always within that favored class, but only certain putative fathers are included."); Michael $M_{\text {. }}$. Superior Court, 450 
A third theme in the case law hinges on an analogy to race discrimination. This line of reasoning emerged early in the sex discrimination jurisprudence, in Frontiero v. Richardson (1973).$^{27}$ Frontiero was decided two years after the Supreme Court first struck down a statute on the ground that it denied women the equal protection of the laws, ${ }^{28}$ but before Craig held that heightened scrutiny would apply to sex-based state action. ${ }^{29}$ The four-Justice plurality opinion in Frontiero contended that sex-based state action should be subject to the same strict scrutiny standard applied to race-based state action, ${ }^{30}$ and repeatedly compared sex and race discrimination. It noted, for instance, that "sex, like race and national origin, is an immutable characteristic determined solely by the accident of birth." ${ }^{31}$ In drawing this analogy,

U.S. $464,466,472-73$ (1981) (plurality opinion) (“[California's statutory rape law] makes men alone criminally liable for the act of sexual intercourse.... We hold that such a statute is sufficiently related to the State's objectives to pass constitutional muster. Because virtually all of the significant harmful and inescapably identifiable consequences of teenage pregnancy fall on the young female, a legislature acts well within its authority when it elects to punish only the participant who, by nature, suffers few of the consequences of his conduct."); Parham v. Hughes, 441 U.S. 347, 348-49, 355 (1979) (plurality opinion) ("Under [Georgia law], the mother of an illegitimate child can sue for the wrongful death of that child... A father who has not legitimated a child, however, is precluded from maintaining a wrongfuldeath action.... [T] he Georgia statute does not invidiously discriminate against the appellant simply because he is of the male sex. The fact is that mothers and fathers of illegitimate children are not similarly situated. ... Unlike the mother of an illegitimate child whose identity will rarely be in doubt, the identity of the father will frequently be unknown.").

For a prominent recent example of this mode of reasoning, see Tuan Anh Nguyen v. Immigration \& Naturalization Serv., 533 U.S. 53, 58-60 (2001) ("We hold that $\& 1409$ (a) is consistent with the constitutional guarantee of equal protection.... [, although it] imposes a set of requirements on the children of citizen fathers born abroad and out of wedlock to a noncitizen mother that are not imposed under like circumstances when the citizen parent is the mother."); id. at 62 ("The first governmental interest to be served is the importance of assuring that a biological parent-child relationship exists. In the case of the mother, the relation is verifiable from the birth itself.... In the case of the father, the uncontestable fact is that he need not be present at the birth."); id. at 64-65 ("The second important governmental interest furthered in a substantial manner by $\S 1409(\mathrm{a})(4)$ is the determination to ensure that the child and the citizen parent have some demonstrated opportunity or potential to develop ... the real, everyday ties that provide a connection between child and citizen parent and, in turn, the United States. In the case of a citizen mother and a child born overseas, the opportunity for a meaningful relationship between citizen parent and child inheres in the very event of birth, an event so often critical to our constitutional and statutory understandings of citizenship.... The same opportunity does not result from the event of birth, as a matter of biological inevitability, in the case of the unwed father.") (citation omitted).

27. 411 U.S. 677 (1973) (plurality opinion).

28. See Reed v. Reed, 404 U.S. 71, 76-77 (1971).

29. See Craig v. Boren, 429 U.S. 190, 197 (1976).

30. See Frontiero, 411 U.S. at 682 ("[A]ppellants contend that classifications based upon sex, like classifications based upon race, alienage, and national origin, are inherently suspect and must therefore be subjected to close judicial scrutiny. We agree ...."); id. at 688 ("[W]e can only conclude that classifications based upon sex, like classifications based upon race, alienage, or national origin, are inherently suspect, and must therefore be subjected to strict judicial scrutiny.").

31. Id. at 686. Along the same lines, the Frontiero plurality explained that "what differentiates sex from such nonsuspect statuses as intelligence or physical disability, and aligns it 
the opinion never focused on the particular situation of women of color. Instead, it used white women to represent all women, and then compared white women to black men. For example, the opinion analogized the history of (white) women and (male) AfricanAmericans, briefly recounting that:

throughout much of the 19th century the position of women in our society was, in many respects, comparable to that of blacks under the preCivil War slave codes. Neither slaves nor women could hold office, serve on juries, or bring suit in their own names, and married women traditionally were denied the legal capacity to hold or convey property or to serve as legal guardians of their own children. ${ }^{32}$

Ultimately, of course, the Court decided to apply intermediate rather than strict scrutiny to sex-based state action, which suggested that sex discrimination was not quite analogous to race discrimination and of lesser constitutional concern for that reason. But the Court has continued to employ the comparison between race and sex discrimination as a prominent explanation for why sex discrimination merits special constitutional scrutiny, returning to this contention repeatedly in the years since Craig. ${ }^{33}$

Against this background, one might expect the Court to have, for instance, easily struck down all forms of sex-segregated public education under heightened scrutiny. Single-sex public schooling, after all, explicitly distinguishes between students based on sex, and has no obvious connection to gestation or to any other fact about the body universally true of all men or all women. What's more, the potential analogy to race discrimination could not be clearer or more patently available. In Brown v. Board of Education (1954), ${ }^{34}$ the Supreme Court famously held that racial segregation in public schools is always unconstitutional, whether or not the excluded race has access to public educational opportunities that are "separate but equal" in resources, facilities, and other material advantages. ${ }^{35}$ Since Brown, racial segrega-

with the recognized suspect criteria, is that the sex characteristic frequently bears no relation to ability to perform or contribute to society." Id.

32. Id. at 685.

33. See, e.g., J.E.B. v. Alabama ex rel. T.B., 511 U.S. 127, 136 (1994) ("As a plurality of this Court observed in Frontiero v. Richardson, 411 U.S., at 685: '[T]hroughout much of the 19 th century the position of women in our society was, in many respects, comparable to that of blacks under the pre-Civil War slave codes." ); $i d$. ("Certainly, with respect to jury service, African-Americans and women share a history of total exclusion, a history which came to an end for women many years after the embarrassing chapter in our history came to an end for African-Americans."); Johnson v. Robison, 415 U.S. 361, 375 n.14 (1974) ("With respect to appellee's second contention [that 'conscientious objectors are a suspect class deserving special judicial protection'], we find the traditional indicia of suspectedness lacking in this case. The class does not possess an 'immutable characteristic determined solely by the accident of birth,' Frontiero v. Richardson, 411 U.S., at 686 ....").

34. 347 U.S. 483 (1954).

35. See id. at 493-95. 
tion in public education has become the Court's paradigm example of unconstitutional race discrimination. ${ }^{36}$

Yet the constitutional law of sex-segregated public education actually constitutes a striking example of the Court's continued uncertainty about which forms of sex-based state action are unconstitutional under heightened scrutiny, and why. Although the Court has desegregated some single-sex public schools, it has always done so on the ground that the particular school in question violated the requirements of even a separate but equal regime, excluding students based on sex when the students did not have access to equal public educational opportunities elsewhere in the jurisdiction. The Court, moreover, has explicitly avoided making any judgments about the constitutionality of sex-segregated public education under conditions of material parity, strongly suggesting that it believes that this form of sex-based state action presents a difficult constitutional question. At the same time, the Court has been unable to explain the source of that intuition. ${ }^{37}$

Consider the first two of the Supreme Court's three cases on sexsegregated public education under heightened scrutiny. ${ }^{38}$ In the first

36. See, e.g., Miller v. Johnson, 515 U.S. 900,911 (1995) ("Just as the State may not, absent extraordinary justification, segregate citizens on the basis of race in its ... schools, Brown v. Board of Education, 347 U.S. 483 (1954), so did we recognize in Shaw that it may not separate its citizens into different voting districts on the basis of race."); Wygant $v$. Jackson Bd. of Educ., 476 U.S. 267, 276 (1986) ("Carried to its logical extreme, the idea that black students are better off with black teachers could lead to the very system the Court rejected in Brown v. Board of Education, 347 U.S. 483 (1954) (Brown I )."); Bob Jones Univ. v. United States, 461 U.S. 574, 593 (1983) ("An unbroken line of cases following Brown v. Board of Education establishes beyond doubt this Court's view that racial discrimination in education violates a most fundamental national public policy, as well as rights of individuals.").

37. For this reason, I do not find Mary Anne Case's recent argument about the current state of the sex discrimination jurisprudence to be fully persuasive. On her account, the Court's sex discrimination case law is governed by a clear, established, and unwavering principle: The Court will only uphold sex-based state action where "the assumption at the root of the sex-respecting rule [is] true of either all women or no women or all men or no men; there must be a zero or a hundred on one side of the sex equation or the other." Mary Anne Case, "The Very Stereotype the Law Condemns": Constitutional Sex Discrimination Law as a Quest for Perfect Proxies, 85 CORNELL L. REv, 1447, 1449-50 (2000); see also id. at 1457 ("Descriptively, while I do not claim that the perfect proxies the Court found are good ones, I do claim (1) that the majority found a perfect proxy in every sex-respecting rule the Court upheld since Frontiero, and (2) for every sex-respecting rule struck down since Frontiero, no perfect proxy, even a farfetched one, occurred to the court, or to me."). It is not at all obvious that the constitutional law of sex-segregated public education can be characterized in these terms, however. As mentioned above, sex-segregated schooling seems to have no apparent connection to gestation or to facts about the body that are universally true of all men or all women. According to Case's account of the sex discrimination jurisprudence, it should have been easy for the Court to categorically prohibit all forms of sex-segregated public education (with the possible exception of something like sex-segregated public education geared to pregnant students). Yet the Court does not seem to agree that sex-segregated public education presents an easy case under heightened scrutiny.

38. Before the Supreme Court established heightened scrutiny for sex-based state action, or struck down any statute on the ground that it represented unconstitutional sex dis- 
case, Vorchheimer v. School District (1977), ${ }^{39}$ Susan Lynn Vorchheimer challenged the exclusion of female students from Central High School, an academically elite and selective public high school for boys in Philadelphia. ${ }^{40}$ By the time the case reached the Supreme Court, a district court had found, ${ }^{41}$ and an'appeals court had agreed ${ }^{42}$ that the educational opportunities available to male students at Central High were "comparable" to those available to female students at the Philadelphia High School for Girls, the only other academically elite and selective public high school in Philadelphia. ${ }^{43}$ The Supreme Court chose Vorchheimer for its first consideration of sex-segregated public education under heightened scrutiny, but could not decide the case. The Court split four-to-four in Vorchheimer, without issuing any opinions. ${ }^{44}$ The Third Circuit's judgment, which had upheld women's exclusion from Central High, ${ }^{45}$ was just affirmed

crimination, the Court summarily affirmed a district court judgment upholding the exclusion of men from Winthrop College under rational basis review. See Williams v. McNair, 401 U.S. 951, 951 (1971) (mem.), affg 316 F. Supp. 134, 135-38 (D.S.C. 1970).

39. 430 U.S. 703 (1977) (per curiam).

40. See Vorchheimer v. Sch. Dist., 532 F.2d 880, 880-81 (3d Cir. 1976).

41. See Vorchheimer v. Sch. Dist., 400 F. Supp. 326, 327, 329 (E.D. Pa. 1975).

42. See Vorchheimer, 532 F.2d at 882 ("The courses offered by the two schools are similar and of equal quality. The academic facilities are comparable, with the exception of those in the scientific field where Central's are superior. The district court concluded 'that [generally] the education available to the female students at Girls is comparable to that available to the male students at Central."'); id. ("A fair summary of the parties' positions, therefore, is that:... the schools for boys and girls are comparable in quality, academic standing, and prestige....").

43. In truth, this factual conclusion was highly suspect, grounded in a casual and cursory interpretation of separate but equal principles. As its very name implies, Central High School, the first public high school in Philadelphia and one of the earliest public high schools in the United States, see Vorchheimer, $400 \mathrm{~F}$. Supp, at 328; infra text accompanying notes $100-102$, was at the pinnacle of Philadelphia's educational system in a way that the High School for Girls was not. The district court's own opinion in Vorchheimer suggested that Central High had more programs, more facilities, more qualified teachers, more books, more financial support, more prestige, and more prominent alumni than its female counterpart. See Vorchheimer, 400 F. Supp. at 328-29; see also Newberg v. Bd. of Pub. Educ., 26 Pa. D. \& C.3d 682, 685-92, 696-99, 703-04 (C.P. Phila. County 1983) (elaborating on these disparities), appeal from final adjudication quashed, 478 A.2d 1352 (Pa. Super. Ct. 1984); FRANKLIN SPENCER EDMONDS, History OF THE CENTRAL HIGH SCHOOL OF PHILADELPHIA 83 (1902) (providing a book-length account of the resources and illustrious history of Central High School that describes, for example, Central High's observatory, "the fourth oldest in America").

44. See Vorchheimer, 430 U.S. at 703. "MR. JUSTICE REHNQUIST took no part in the consideration or decision of this case," leaving only eight Justices remaining. Id.

45. See Vorchheimer, 532 F.2d at 881, 886. Female students would not gain access to Central High School until they went to Pennsylvania state court in 1983. In this second suit, the plaintiffs again argued that the High School for Girls failed to offer women equivalent educational opportunities. See Newberg, 26 Pa. D. \& C.3d at 683-84. In this case, however, the court conducted a much more rigorous separate but equal analysis and desegregated Central High, holding that Vorchheimer's counsel had provided such materially inadequate representation in developing the facts of the case that the plaintiffs in the state suit could not be bound by the earlier factual findings. See id. at 702-07, 711-12. 
automatically on the basis of the divided vote..$^{46}$

The Court's second case on sex-segregated public education under heightened scrutiny, Mississippi University for Women v. Hogan (1982), ${ }^{47}$ also left the constitutional status of "'separate but equal"" sex-segregated public education unresolved, explicitly reserving judgment on that question. ${ }^{48}$ The Hogan Court ordered the School of Nursing in the Mississippi University for Women to admit men simply on the ground that the men excluded from the school did not have access elsewhere in Mississippi to the public educational opportunities available to women. ${ }^{49}$

Vorchheimer and Hogan appear to reflect the Court's belief that sex-segregated public education raises complex constitutional questions. But the Court was unable in either case to offer an adequate explanation of the reasoning behind that assessment.

One line of thought visible in the cases drew on a particular vision of the history of sex-segregated public education, which incorrectly imagined the record of this practice to be wholly benign, uncontested, structured for the mutual benefit of men and women, and not worth further investigation. ${ }^{50}$ This theory featured prominently in the Third

46. See Vorchheimer, 430 U.S. at 703.

47. 458 U.S. 718 (1982).

48. Id. at $720 \mathrm{n} .1$ ("Mississippi maintains no other single-sex public university or college. Thus, we are not faced with the question of whether States can provide 'separate but equal' undergraduate institutions for males and females. Cf. Vorchheimer v. School District of Philadelphia, 532 F.2d 880 (CA3 1975), aff'd by an equally divided Court, 430 U.S. 703 (1977)."). In his dissent in Hogan, Justice Blackmun indicated that he would uphold the constitutionality of sex-segregated public education that was "'separate but equal." $I d$. at 734 (Blackmun, J., dissenting) (complaining that the majority opinion in Hogan "places in constitutional jeopardy any state-supported educational institution that confines its student body in any area to members of one sex, even though the State elsewhere provides an equivalent program to the complaining applicant").

49. The opinion did not elaborate much on what "separate but equal" standards required, but it explained that those principles were violated in this case because Mississippi operated no all-male nursing school and its coeducational nursing programs were located "a considerable distance from" the male plaintiff's home. $l d$. at $720 \&$ n.1, 723 \& n.8. The Court limited its opinion to the School of Nursing in particular, without addressing the admissions policies for the rest of the Mississippi University for Women. See id, at 723 n.7.

50. The impulse to assert that women have consensually agreed to the status they occupy is deeply rooted in American law and society and appears in a wide variety of contexts. For example, I recently explored contemporary debates over the legal status of marital rape. People on both sides of these debates consistently assume that the law's protection of marital rape did not become controversial until the late twentieth century. Although the historical record clearly contradicts that notion, its prevalence reflects and draws strength from a common presumption holding that long-established aspects of women's legal status must have survived into the contemporary era because they embody a set of shared norms, long endorsed by women and men alike. See Jill Elaine Hasday, Contest and Consent: $A$ Legal History of Marital Rape, 88 CAL. L. REV. 1373, 1375-85, 1485-90, 1498-1505 (2000); see also id. at 1382-85 (arguing that this presumption also shapes many historical accounts of the first woman's rights movement). For work exploring related assumptions about women's consent, see Vicki Schultz, Telling Stories About Women and Work: Judicial Interpretations of Sex 
Circuit's opinion in Vorchheimer ${ }^{51}$ and was also endorsed by Justice Powell's dissent in Hogan. Powell asserted that sex-segregated public education could be constitutional in some contexts because it was not the product of "any discriminatory animus." 52 He presented no historical evidence to undergird this conclusion, but drew on some deeper certainty to report that "[t]he sexual segregation of students has been a reflection of, rather than an imposition upon, the preference of those subject to the policy." ${ }^{\text {33 }}$ With this consensual view of the history of sexsegregated public education in mind, moreover, Powell also found it

Segregation in the Workplace in Title VII Cases Raising the Lack of Interest Argument, 103 HARV. L. REV. 1749, 1770, 1777 (1990) ("In the[] early race discrimination cases, the courts applied evidentiary standards that presumed that continuing patterns of racial segregation were attributable to historical labor market discrimination, rather than to minorities' independent preferences for lower-paying, less-challenging jobs... . [In contrast,] almost half the courts considering the issue have attributed sex segregation to women's own work preferences."); Reva B. Siegel, Collective Memory and the Nineteenth Amendment: Reasoning About "the Woman Question" in the Discourse of Sex Discrimination, in HISTORY, MEMORY, AND THE LAW 131, 133 (Austin Sarat \& Thomas R. Kearns eds., 1999) ("This essay argues that the prevailing understanding of the suffrage amendment reflects habits of reasoning about gender relations that it in turn helps sustain. At the level of common sense, we do not understand gender relations to have a political history in anything like the way we understand race relations to have a political history: the narrative structures through which we explain the relations of the sexes depict gender arrangements as the product of consensus and custom rather than coercion and conflict. Our understanding of the Nineteenth Amendment both reflects and sustains these habits of reasoning.").

51. The Third Circuit in Vorchheimer emphasized that sex-segregated public education was not rooted in discrimination against women and girls. "If there are benefits or detriments inherent in the system," the court explained, "they fall on both sexes in equal measure." Vorchheimer v. Sch. Dist., 532 F.2d 880, 886 (3d Cir. 1976). Although it was unclear where the court's certainty came from, it appeared to be based on this sort of picture of the past.

On the Third Circuit's account, all-male public schools like Central High had established their exclusionary admissions policies out of innocuous pedagogical motives that were designed to operate to the shared advantage of boys and girls. "[T]he special emotional problems of the adolescent years are matters of human experience and have led some educational experts to opt for one-sex high schools," the court recounted. "While this policy has limited acceptance on its merits, it does have its basis in a theory of equal benefit and not discriminatory denial." Id. at 887 ; see also id. at 888 ("[G]iven the objective of a quality education and a controverted, but respected theory that adolescents may study more effectively in single-sex schools, the policy of the school board here does bear a substantial relationship."). This was more a conclusory statement about the history of "the time honored educational alternative of sexually-segregated high schools," $i d$ at 882 , than an actual account of that history. The Third Circuit, for example, offered no explanation for why Central High was established exclusively for boys, long before Philadelphia's girls had any opportunity to obtain a public high school education, nor did it discuss who had made that judgment. But the Third Circuit appeared to rely on its vision of history, nonetheless, in holding that constitutional courts had no responsibility to end women's exclusion from male public schools, as long as equivalent public educational opportunities were available elsewhere in the jurisdiction.

52. Hogan, 458 U.S. at 737 n.3 (Powell, J., dissenting).

53. Id. at 737 (Powell, J., dissenting); see also id. at 744 (Powell, J., dissenting) ("IT]he practice of voluntarily chosen single-sex education is an honored tradition in our country .... Mississippi's accommodation of such student choices is legitimate because it is completely consensual and is important because it permits students to decide for themselves the type of college education they think will benefit them most."). 
easy to dismiss any comparisons with racially segregated public education, which he took to have a malevolent and coercive past. Sexsegregated public education, Powell explained, had historically operated to expand women's choices. It therefore "differ[ed] from the tradition, typified by the decision in Plessy v. Ferguson, of 'separate but equal' racial segregation" because "[i]t was characteristic of racial segregation that segregated facilities were offered, not as alternatives to increase the choices available to blacks, but as the sole alternative." 54

The Hogan majority endorsed a different argument. This line of reasoning stressed that the history of sex-segregated public education was of no constitutional relevance at all. It offered, however, no alternate explanation for the Court's instinct that sex-segregated public education could be constitutional.

Mississippi's "primary justification" in Hogan for excluding men from the School of Nursing was "that it compensate[d] for discrimination against women." In support of this contention, Mississippi explained that the Mississippi University for Women had been founded in 1884 "to provide some form of higher education for the academically disenfranchised," because the University of Mississippi banned female students before 1882 , and then alternately prohibited and discouraged the admission of (white) women until after $1920 .^{56}$ The Hogan Court accepted this historical account, which suggested that the practice of sex-segregated public education might be historically entangled in the law's denial of equal status to women. But the Hogan majority simultaneously made clear that it did not matter whether a school's admissions policy had been part of the history of women's legalized inequality, or a response and counterweight to it, or both. ${ }^{57} \mathrm{On}$ the Court's view, Mississippi's only hope for establishing a record of discrimination that might affect the constitutionality of the School of Nursing's admissions policy would require the state to demonstrate that discrimination currently deprived women of adequate opportunities to obtain nursing training and to prove that the state intended for

54. Id. at $741 \mathrm{n} .9$ (Powell, J., dissenting) (citation omitted). Justice Blackmun's dissent in Hogan also rejected, without explanation, the analogy between educational segregation based on race and educational segregation based on sex. See id. at 734-35 (Blackmun, J., dissenting) ("I hope that we do not lose all values that some think are worthwhile (and are not based on differences of race or religion) and relegate ourselves to needless conformity.") (emphasis added).

55. Id. at 727 .

56. Id. at 727 n.13.

57. For more discussion of the founding of the Mississippi University for Women, originally the Mississippi Industrial Institute and College for the Education of White Girls of the State of Mississippi in the Arts and Sciences, see infra text accompanying notes 113, 125-127, 168-169. 
the single-sex admissions policy at the School of Nursing to compensate for that current practice of discrimination. ${ }^{58}$

Of course, Hogan's rejection of the constitutional relevance of history could not affirmatively account for its impulse to protect certain forms of sex-segregated public education. The Hogan Court made space for the possibility of "separate but equal" sex segregation, even though this was an example of the very sort of explicit sex-based classification that the law of heightened scrutiny otherwise targeted. ${ }^{59}$ Indeed, it left room for more than that. In rejecting Mississippi's argument from history, the Hogan Court at least implied that even asymmetrical sex segregation in public schooling might be constitutionally permissible if it responded to current (rather than past) inequities, a position that would place the law of sex-segregated public education in even starker contrast to the constitutional jurisprudence on racially segregated public schools. ${ }^{60}$ Yet the Court was never able to explain its intuition that sex segregation in public education could be constitutional.

\section{B. "Full Citizenship Stature" and "Legal, Social, and Economic Inferiority"}

In light of the Court's persistent uncertainty about the reach and reasoning of heightened scrutiny, it is worth noting that one of the Court's newest sex discrimination opinions purports to offer a more cogent framework. In United States v. Virginia (1996), ${ }^{61}$ the Court's most recent decision on sex-segregated public education, the United States challenged the constitutionality of women's exclusion from the Virginia Military Institute (VMI), a public college organized "to produce 'citizen-soldiers,' men prepared for leadership in civilian life and in military service." ${ }^{, 2}$ When this suit was initially filed, no public school in Virginia offered women training as "“citizen-soldiers." 63 But Virginia soon opened a Virginia Women's Institute for Leadership (VWIL) in an effort to protect VMI's male-only admissions policy

58. See Hogan, 458 U.S. at $729-30$ \& n.16.

59. Id. at 720 n.1.

60. See id. at 728 ("In limited circumstances, a gender-based classification favoring one sex can be justified if it intentionally and directly assists members of the sex that is disproportionately burdened."). A similar suggestion appeared in Chief Justice Burger's dissent. See id. at 733 (Burger, C.J., dissenting) ("[T]he Court's holding today is limited to the context of a professional nursing school. Since the Court's opinion relies heavily on its finding that women have traditionally dominated the nursing profession, it suggests that a State might well be justified in maintaining, for example, the option of an all-women's business school or liberal arts program.") (citations omitted).

61. 518 U.S. 515 (1996).

62. Id. at 519-20.

63. Id at 520 . 
from legal intervention. ${ }^{64}$ In many respects, the Supreme Court's response to this case was very traditional. The Court easily determined that Virginia's sex-segregated educational system, even with VWIL included, did not satisfy separate but equal standards. VMI had more prestige than VWIL, ${ }^{65}$ more resources, ${ }^{66}$ more course offerings, ${ }^{67}$ more qualified teachers, ${ }^{68}$ more influential and loyal alumni, ${ }^{69}$ and a unique method of training students, ${ }^{70}$ and its exclusion of women was unconstitutional for that reason..$^{71}$ As the Virginia Court observed, there were women qualified in all but sex to attend $\mathrm{VMI},{ }^{72}$ and when the

64. See id. at 525-26.

65. See id. at 557 ("VMI, too, offers an educational opportunity no other Virginia institution provides, and the school's 'prestige'-associated with its success in developing "citizen-soldiers"-is unequaled.").

66. See id. at 520 ("VMI's endowment reflects the loyalty of its graduates; VMI has the largest per-student endowment of all public undergraduate institutions in the Nation.").

67. See id. at 557 ("Virginia has closed this facility to its daughters and, instead, has devised for them a 'parallel program,' with a faculty less impressively credentialed and less well paid, more limited course offerings, fewer opportunities for military training and for scientific specialization.").

68. See id.

69. See id. at 520 ("VMI has notably succeeded in its mission to produce leaders; among its alumni are military generals, Members of Congress, and business executives. The school's alumni overwhelmingly perceive that their VMI training helped them to realize their personal goals.").

70. See id. ("VMI's distinctive mission is to produce 'citizen-soldiers,' men prepared for leadership in civilian life and in military service. VMI pursues this mission through pervasive training of a kind not available anywhere else in Virginia.").

71. See id. at 519 ("The United States maintains that the Constitution's equal protection guarantee precludes Virginia from reserving exclusively to men the unique educational opportunities VMI affords. We agree."); $i d$. at 534 ("Because the remedy proffered by Virginia-the Mary Baldwin VWIL program-does not cure the constitutional violation, i.e., it does not provide equal opportunity, we reverse the Fourth Circuit's final judgment in this case."); id. at 557 ("VMI, beyond question, 'possesses to a far greater degree' than the VWIL program 'those qualities which are incapable of objective measurement but which make for greatness in a ... school,' including 'position and influence of the alumni, standing in the community, traditions and prestige.' Women seeking and fit for a VMI-quality education cannot be offered anything less, under the Commonwealth's obligation to afford them genuinely equal protection." (quoting Sweatt v. Painter, 339 U.S. 629, 634 (1950))).

72. See, e.g., id. at 525 ("The parties agreed that 'some women can meet the physical standards now imposed on men,' and the court was satisfied that 'neither the goal of producing citizen soldiers nor VMI's implementing methodology is inherently unsuitable to women." (quoting 976 F.2d at 896, 899)); $i d$. at 540 ("It is also undisputed ... that 'the VMI methodology could be used to educate women.' The District Court even allowed that some women may prefer it to the methodology a women's college might pursue." (quoting $852 \mathrm{~F}$. Supp. at 481)); id. at 540-41 ("“[S]ome women, at least, would want to attend [VMI] if they had the opportunity,' the District Court recognized, and 'some women,' the expert testimony established, 'are capable of all of the individual activities required of VMI cadets."' (quoting 766 F. Supp. at 1414, 1412)) (alterations in original); id. at 542 ("The issue . . is not whether 'women-or men-should be forced to attend VMI'; rather, the question is whether the Commonwealth can constitutionally deny to women who have the will and capacity, the training and attendant opportunities that VMI uniquely affords." (quoting 52 F.3d at 93)); id. at 550 (" $[\mathrm{G}]$ eneralizations about 'the way women are,' estimates of what is appropriate 
school excluded them they did not have access to equivalent public educational opportunities elsewhere in the state. ${ }^{73}$ Like Hogan before it, Virginia explicitly reserved judgment on whether separate but equal sex segregation could be constitutional. ${ }^{74}$

At the same time, however, the Virginia Court also appeared to suggest a new basis for determining which forms of sex-based state action represent unconstitutional sex discrimination and why. ${ }^{75}$ Most of

for most women, no longer justify denying opportunity to women whose talent and capacity place them outside the average description.").

73. See supra text accompanying notes 65-71.

74. As the Court explained:

We address specifically and only an educational opportunity recognized by the District Court and the Court of Appeals as "unique," an opportunity available only at Virginia's premier military institute, the Commonwealth's sole single-sex public university or college. Cf. Mississippi Univ. for Women v. Hogan, 458 U.S. 718, 720, n. 1 (1982) ("Mississippi maintains no other single-sex public university or college. Thus, we are not faced with the question of whether States can provide 'separate but equal' undergraduate institutions for males and females.").

Virginia, 518 U.S. at 534 n.7 (citations omitted). Rehnquist's concurrence, in turn, indicated that he would uphold the constitutionality of sex-segregated public education where the state operated a single-sex school for each sex, rather than just one, and "the two institutions offered the same quality of education and were of the same overall caliber." Id. at 565 (Rehnquist, C.J., concurring in judgment).

75. Thus far, the Court's opinion in Virginia has attracted critical attention mainly for what it might indicate about the level of constitutional scrutiny appropriately applied to sexbased state action. In some passages of the Virginia opinion, the Court explained that explicit legal classifications based on sex can only survive constitutional challenge if they have "an 'exceedingly persuasive justification." Id. at 531; see also id. at 532-34. A number of scholars have read these statements to mean that the Court will now apply a more skeptical form of review to sex-based legal classifications, and this contention has been a central focus of scholarly debate over the opinion. See, e.g., Larry Catá Backer, Reading Entrails: Romer, VMI, and the Art of Divining Equal Protection, 32 TULSA L.J. 361, 369 (1997) ("[Justice Ginsburg writing for the Court in Virginia] certainly meant to push the Court as far as she could in the direction of strict scrutiny. I am less inclined to believe that the rest of the six concurring Justices are fellow travelers in this particular hermeneutical journey. But that may not matter-the intermediate courts may take the hint and make it increasingly impossible for the high court to contain the language of the opinion."); Deborah L. Brake, Reflections on the VMI Decision, 6 AM. U. J. GENDER \& L. 35, 36 (1997) ("While the Court stopped short of explicitly adopting strict scrutiny for sex-based classifications, the opinion includes a number of indicators suggesting that the standard applied in $V M I$ is essentially as rigorous as today's strict scrutiny standard. Indeed, the analysis the Court applied to strike down VMI's exclusion of women is all but indistinguishable from strict scrutiny."); Jon Gould, The Triumph of Hate Speech Regulation: Why Gender Wins But Race Loses in America, 6 MICH. J. GENDER \& L. 153, 214 (1999) ("In VMI, however, the Court invented a new test for gender classifications that closely resembles the strict scrutiny test of race."); Candace Saari Kovacic-Fleischer, United States v. Virginia's New Gender Equal Protection Analysis with Ramifications for Pregnancy, Parenting, and Title VII, 50 VAND. L. REV. 845, 883 (1997) ("[B]y requiring VMI to make institutional adjustments to admit qualified women, the Court has elevated equal protection analysis to the level of the least-restrictivemeans analysis of strict scrutiny."); Cass R. Sunstein, Foreword: Leaving Things Undecided, 110 HARV. L. REV. 4, 73 (1996) ("Virginia heightens the level of scrutiny and brings it closer to the 'strict scrutiny' that is applied to discrimination on the basis of race."); id. at 75 ("[T]he Court did not merely restate the intermediate scrutiny test but pressed it closer to strict scrutiny. After United States v. Virginia, it is not simple to describe the appropriate 
the Court's prior sex discrimination cases had assumed that women have no history of constitutional relevance. Indeed, the brief mention of women's past that appeared in the Frontiero plurality opinion-a sketch meant simply to establish a connection between sex and raceconstitutes the most lengthy account of women's legal history ever included in a Supreme Court sex discrimination opinion before Virginia. ${ }^{76}$ Portions of the Virginia opinion, though, ground the constitutional jurisprudence of sex discrimination in the history of women's unequal status under the law. ${ }^{77}$ More specifically, they suggest that constitutional law has a responsibility to work toward the establishment of women's equal citizenship and the eradication of women's legalized inferiority precisely because women's unequal status is something that the law itself has long helped to create, maintain, and enforce.

In this vision, the sex discrimination jurisprudence has commitments that are broad and substantive. It is intended to give women "full citizenship stature - equal opportunity to aspire, achieve, participate in and contribute to society based on their individual talents and capacities," inferiority." As the Virginia Court explained:

In 1971, for the first time in our Nation's history, this Court ruled in favor of a woman who complained that her State had denied her the equal protection of its laws. Since Reed, the Court has repeatedly recognized that neither federal nor state government acts compatibly with the equal protection principle when a law or official policy denies to women, simply because they are women, full citizenship stature-equal opportunity to aspire, achieve, participate in and contribute to society based on their individual talents and capacities.

standard of review. States must satisfy a standard somewhere between intermediate and strict scrutiny.").

For the contrary argument, see Case, supra note 37, at 1448 ("This Article will demonstrate that Justice Scalia is quite right in his articulation of the standard applied by the majority in $V M I$, but wrong to assert that it is a departure of any kind from precedent.").

76. See supra text accompanying note 32 .

77. The opinion explains that:

Today's skeptical scrutiny of official action denying rights or opportunities based on sex responds to volumes of history. As a plurality of this Court acknowledged a generation ago, "our Nation has had a long and unfortunate history of sex discrimination." Through a century plus three decades and more of that history, women did not count among voters composing "We the People"; not until 1920 did women gain a constitutional right to the franchise. And for a half century thereafter, it remained the prevailing doctrine that government, both federal and state, could withhold from women opportunities accorded men so long as any "basis in reason" could be conceived for the discrimination.

Virginia, 518 U.S. at 531 (quoting Frontiero v. Richardson, 411 U.S. 677, 684-85 (1973)).

78. Id, at 532 .

79. Id. at 534 . 
"Inherent differences" between men and women, we have come to appreciate, remain cause for celebration, but not for denigration of the members of either sex or for artificial constraints on an individual's opportunity. Sex classifications may be used to compensate women "for particular economic disabilities [they have] suffered," to "promot[e] equal employment opportunity," to advance full development of the talent and capacities of our Nation's people. But such classifications may not be used, as they once were, to create or perpetuate the legal, social, and economic inferiority of women. ${ }^{80}$

Building on this theme, the Virginia Court went on to at least suggest that the constitutionality of single-sex public schooling might turn, not just on whether the regime satisfied separate but equal requirements, but on whether the school in question contributed to women's unequal status or not. "Several amici," the Court reported,

have urged that diversity in educational opportunities is an altogether appropriate governmental pursuit and that single-sex schools can contribute importantly to such diversity. Indeed, it is the mission of some single-sex schools "to dissipate, rather than perpetuate, traditional gender classifications." We do not question the Commonwealth's prerogative evenhandedly to support diverse educational opportunities. ${ }^{81}$

This line of reasoning represents a substantially new idea within the constitutional jurisprudence of sex discrimination, one that the Court seems to believe can offer an effective way to determine which forms of state action fail heightened scrutiny and a normative justification for why. But the Court does not begin to tell us how we might take seriously the suggestions that Virginia puts forth. If the constitutional law of sex discrimination is to strike down those forms of sexbased state action that "create or perpetuate the legal, social, and economic inferiority of women," 82 how do we tell which ones they are?

80. Id. at 532-34 (alterations in original) (citations omitted). Denise Morgan has also noted this theme in the Virginia opinion, but she contends that it has been consistently expressed in the Supreme Court's sex discrimination jurisprudence since Frontiero. See Denise C. Morgan, Anti-Subordination Analysis After United States v Virginia: Evaluating the Constitutionality of K-12 Single-Sex Public Schools, 1999 U. CHI. LEGAL F. 381, 383 ("Since the Supreme Court decided Frontiero v Richardson in 1973, constitutional scrutiny of [sexbased] classifications has turned on two considerations: 'fit'- whether the challenged practice actually serves the objective the legislature intended it to serve; and antisubordination'-whether the legislative objective is to disadvantage, and sometimes, whether the challenged practice has subordinating effects."). In my view, however, this line of reasoning in Virginia represents much more of a new development. Virginia suggests that the law's historical role in maintaining women's unequal status provides the normative justification for a doctrine of heightened scrutiny that is grounded in a determination to protect women's equal citizenship and combat their inferiority. In contrast, the Court's prior sex discrimination jurisprudence is pointedly indifferent to women's particular history of legalized inferiority and, frequently, to substantive issues of equality more generally. See supra text accompanying notes $18-20$.

81. Virginia, 518 U.S. at 534 n. 7 (quoting Brief for Twenty-six Private Women's Colleges as Amici Curiae 5).

82. Id. at 534 . 
How would we go about determining what sustains such inferiority and what promotes women's "full citizenship stature," in the context of sex-segregated public education or elsewhere? What would we need to know to decide the next case, if we were to follow Virginia's injunction?

The answers to these questions are hardly obvious. To take the practice most immediately at hand again, there is certainly room for active debate about whether, when, why, and how sex-segregated public education contributes to women's inequality. ${ }^{84}$ Indeed, even the large and expanding body of legal literature written in what might be called the "anti-subordination tradition" does relatively little to help us apply Virginia's suggested legal standard to specific situations. The writers in this tradition would not necessarily agree with the Virginia Court on all counts. But the anti-subordination literature, which has argued for more than three decades that constitutional law enforcing the equal protection guarantee should focus on eradicating subordination, would still seem to have concerns substantially aligned to those that the Virginia opinion articulates. Yet this literature ultimately proves frustrating as a guide to determining which practices deny women "full citizenship stature" or sustain their "legal, social, and economic inferiority." 85

The anti-subordination literature has developed a variety of different accounts of how practices, institutions, and activities can operate to maintain subordination in the United States, and named a variety of harms that subordination can inflict on the members of targeted classes. But although it is generally not remarked upon, ${ }^{86}$ this litera-

\section{Id. at 532 .}

84. For some examples of the wide range of opinion that presently exists on this subject, see 140 CONG. REC. 26,910 (1994) (statement of Rep. Mink) ("[O]nce you begin segregating students by sex, it is the girls that always lose. It was not too many years ago, when girls continued to be forced to take home-making while boys took technical training classes which gave them skills they could easily translate into the marketplace.... [T] but equal ... has never proved to benefit minorities, girls or any other group that has been historically discriminated against in our schools system."); Susan Estrich, For Girls' Schools and Women's Colleges, Separate ls Better, N.Y. TimES, May 22, 1994, § 6 (Magazine), at 38, 39 ("Instead of declaring equality, society should be advancing it. ... One place that happens is in girls' schools and women's colleges. Sometimes separate isn't equal; it's better. Changing the way teachers teach in coed schools, changing the textbooks to make sure they talk about women as well as men, educating parents about raising daughters-all of these things make sense, since most girls will be educated in coed classrooms. But we've' been talking about them for a decade, and the problems of gender bias stubbornly persist.").

85. Virginia, 518 U.S. at $532,534$.

86. For an exception, see KenNETH L. KARST, BELonging to AMERICA: Equal CITIZENSHIP AND THE CONSTIrUTION 237 (1989) ("Identifying equal citizenship as the substantive core of the Fourteenth Amendment does not decide concrete cases. There is as much room for the begging of questions here as in any other general formulation of principle, and no principle of equality can escape the problem of open-endedness. ... 'It merely states the problem,' I heard Judge Hand say on an evening long ago, speaking of his own 
ture has been able to tell us much less about whether a particular practice is subordinating in a particular case and why.

One set of concerns that the anti-subordination literature has identified focuses on what is typically referred to as social meaning. Here, the arguments roughly divide into two categories. The first explains that practices, institutions, and activities can perpetuate subordination by creating, expressing, and/or reinforcing a hegemonic or dominant societal contention that the members of certain groups, like AfricanAmericans or women, are inferior to the members of other groups, like whites or men. ${ }^{87}$ The second, related line of thought, most prominently associated with Kenneth Karst, maintains that practices, institutions, and activities can similarly sustain subordination by promoting a hegemonic contention that the members of certain groups are not part of the national or local community, and in the process can injure the excluded people's sense of self and sense of belonging..$^{88}$

formulation of another issue. The equal citizenship principle merely states the problem of constitutional equality.").

87. See, e.g., Catharine A. Mackinnon, Sexual Harassment of Workino WOMEN: A CASE OF SEX DISCRIMINATION 174 (1979) ("Practices which express and reinforce the social inequality of women to men are clear cases of sex-based discrimination in the inequality approach."); Charles L. Black, Jr., The Lawfulness of the Segregation Decisions, 69 YALE L.J. 421, 427 (1960) ("[I]t would be the most unneutral of principles, improvised ad hoc, to require that a court faced with the present problem refuse to note a plain fact about the society of the United States-the fact that the social meaning of segregation is the putting of the Negro in a position of walled-off inferiority-or the other equally plain fact that such treatment is hurtful to human beings."); Charles R. Lawrence III, If He Hollers Let Him Go: Regulating Racist Speech on Campus, 1990 DUKE L.J. 431, 444 ("Racism is both $100 \%$ speech and $100 \%$ conduct. Discriminatory conduct is not racist unless it also conveys the message of white supremacy-unless it is interpreted within the culture to advance the structure and ideology of white supremacy."); David A. Strauss, Discriminatory Intent and the Taming of Brown, 56 U. CHI. L. REV. 935, 942-43 (1989) ("[The stigma] approach focuses less on the concrete effects that a government action has on a group's position and more on the message that the action conveys to others. ... For example, an explicitly race-neutral policy that had the effect of excluding all blacks from admission to a state university might brand blacks as inferior by conveying the message that, as a group, they are not as capable as whites.").

88. See KARST, supra note 86 , at 3 ("The principle of equal citizenship, as I use the term, means this: Each individual is presumptively entitled to be treated by the organized society as a respected, responsible, and participating member. Stated negatively, the principle forbids the organized society to treat an individual as a member of an inferior or dependent caste or as a nonparticipant. The principle thus centers on those aspects of equality that are most closely bound to the sense of self and the sense of inclusion in a community."); $i d$. at 4 ("Claims to equal citizenship have always carried an emotional charge in America, especially when inequalities have attached to such attributes as race, sex, religion, or ethnicity. These matters touch the heart because they touch the sense of belonging and therefore the sense of self. Belonging is a basic human need... The most heartrending deprivation of all is the inequality of status that excludes people from full membership in the community, degrading them by labeling them as outsiders, denying them their very selves."); id. at 11 ("This book focuses on the hurt of exclusion. In the perspective offered here, citizenship means not just rights but responsibility, not just autonomy but belonging."); see also Lawrence, supra note 87, at 438-39 "'Brown can also be read more broadly to articulate a principle central to any substantive understanding of the equal protection clause, the foundation on which all antidiscrimination law rests. This is the principle of equal citizenship. Under that principle 'every individual is presumptively entitled to be treated by the organized society as a respected, 
Linked to this discussion of social meaning, writers in the antisubordination tradition have also argued that practices, institutions, and activities can promote subordination by inflicting dignitary harms on the members of targeted groups. In this case, concern centers on practices that treat the members of disfavored classes as unworthy of equal respect and dignity and instead subject them to humiliation, stigmatization, denigration, and degradation. ${ }^{89}$

Finally, and most concretely, anti-subordination writers argue that practices, institutions, and activities can foster subordination by inflicting a wide variety of material harms on the members of targeted populations. Speaking generally, these writers have identified two, connected categories of material harm. ${ }^{90}$ The first, emphasized by Owen Fiss, Cass Sunstein, and others, focuses on classic indicators of socioeconomic status and social welfare, explaining that practices cause subordinating material harm when they systematically leave the members of targeted groups with less wealth, less political power, less protection from private or public violence, less education, less health, less life expectancy, less access to housing, and/or less leisure. ${ }^{91}$ The

responsible, and participating member.' Furthermore, it requires the affirmative disestablishment of societal practices that treat people as members of an inferior or dependent caste, as unworthy to participate in the larger community." (quoting Karst)).

89. See, e.g., MACKINNON, supra note 87 , at 47 ("Women's feelings about their experiences of sexual harassment are a significant part of its social impact. Like women who are raped, sexually harassed women feel humiliated, degraded, ashamed, embarrassed, and cheap, as well as angry."); J.M. Balkin, The Constitution of Status, 106 YALE L.J. 2313, 2321 (1997) ("Social status is the degree of prestige and honor that individuals or groups enjoy. This prestige involves the approval, respect, admiration, or positive qualities imputed to a person or group. Lower social status confers and imputes corresponding disapproval and negative qualities. Although individuals may have different degrees of status within a single group, they also have status because they are members of a group. One can have higher or lower status, for example, because one is an immigrant, a woman, or a member of 'the upper crust.' Critical race scholars have repeatedly noted that white Americans have certain status privileges conferred on them merely by being white."); Cass R. Sunstein, The Anticaste Principle, 92 MICH. L. REV. 2410, 2430 (1994) ("A particular concern is that self-respect and its social bases ought not to be distributed along the lines of race and gender. When someone is a member of a group that is systematically subordinate to others, and when the group characteristic is highly visible, insults to self-respect are likely to occur nearly every day. An important aspect of a system of caste is that social practices produce a range of obstacles to the development of self-respect, largely because of the presence of the highly visible but morally irrelevant characteristic that gives rise to lower-caste status.").

90. Although we generally categorize the anti-subordination tradition in different ways, David Strauss also notes a divide along these lines. See Strauss, supra note 87, at $941-42$ ("There seem to be two ways of understanding subjugation or subordination. One focuses on the accumulation of disadvantages. A racial group that is worse off than all others in nearly every significant measure of human welfare might be said to be a 'subject race.' The second emphasizes the state of being personally subject to the will of another. Slavery was the clearest case of subordination. Under this view, the distinctive characteristic of a subordinated group is that its members are systematically subject to violence at the hands of members of another group, or must systematically yield to the commands of members of another group.").

91. See Owen M. Fiss, Groups and the Equal Protection Clause, 5 PHIL. \& PuB. AfF. 107,150 (1976) ("[Blacks] have two gther chacacteristics as a group that are critical in under- 
second focuses on control and autonomy, explaining that practices cause subordinating material harm when they systematically leave the members of targeted groups with less control or power over their own lives and more subject to the control and direction of another person or the state. ${ }^{92}$

Taken together, this body of work provides some important guidance and criteria. For example, this literature explains that practices can cause subordination by inflicting dignitary or material injury on individuals in targeted classes. This is definitely helpful information. Yet at the same time, it does not reveal whether any particular prac-

standing the function and reach of the Equal Protection Clause. One is that blacks are very badly off, probably our worst-off class (in terms of material well-being second only to the American Indians), and in addition they have occupied the lowest rung for several centuries. In a sense, they are America's perpetual underclass."); id. at 151-52 ("It is not just the socioeconomic status of blacks as a group that explains their special position in equal protection theory. It is also their political status. The power of blacks in the political arena is severely limited."); Sunstein, supra note 89 , at 2429 ("The motivating idea behind an anticaste principle is that without good reason, social and legal structures should not turn differences that are both highly visible and irrelevant from the moral point of view into systematic social disadvantages. A systematic disadvantage is one that operates along standard and predictable lines in multiple and important spheres of life and that applies in realms that relate to basic participation as a citizen in a democracy. There is no algorithm by which to identify those realms. As a provisional working list, we might include education, freedom from private and public violence, income and wealth, political representation, longevity, health, and political influence."); see also Ruth Colker, Anti-Subordination Above All: Sex, Race, and Equal Protection, 61 N.Y.U. L. REV, 1003, 1007 (1986) ("In this Article, I argue that courts should analyze equal protection cases from an anti-subordination perspective. Under the antisubordination perspective, it is inappropriate for certain groups in society to have subordinated status because of their lack of power in society as a whole. This approach seeks to eliminate the power disparities between men and women, and between whites and nonwhites, through the development of laws and policies that directly redress those disparities."); Kimberle Williams Crenshaw, Race, Reform, and Retrenchment: Transformation and Legitimation in Antidiscrimination Law, 101 HARV. L. REV. 1331, 1377 (1988) ("Material subordination ... refers to the ways that discrimination and exclusion economically subordinated Blacks to whites and subordinated the life chances of Blacks to those of whites on almost every level. This subordination occurs when Blacks are paid less for the same work, when segregation limits access to decent housing, and where poverty, anxiety, poor health care, and crime create a life expectancy for Blacks that is five to six years shorter than for whites.").

92. See, e.g., MACKINNON, supra note 87 , at 216 ("Sexual harassment at work critically undercuts women's potential for work equality as a means to social equality. Beyond survival, employment outside the home may offer women some promise of developing a range of capacities for which the nurturing, cleaning, and servant role of housework and child care provide little outlet. A job, no matter how menial, offers the potential for independence from the nuclear family, which makes women dependent upon men for life necessities."); Katherine M. Franke, What's Wrong with Sexual Harassment?, 49 STAN. L. REV. 691, 760 (1997) ("The anti-subordination principle could be greatly improved by conceptualizing the problem as one of gender subordination defined in hetero-patriarchal terms. Thus, sexual harassment is understood as a mechanism by which an orthodoxy regarding masculinity and femininity is enforced, policed, and perpetuated in the workplace."); Reva Siegel, Reasoning from the Body: A Historical Perspective on Abortion Regulation and Questions of Equal Protection, 44 STAN. L. REV. 261, 351 (1992) ("From a historical perspective it is clear that abortion-restrictive regulation is caste legislation, a traditional mode of regulating women's conduct, concerned with compelling them to perform the work that has traditionally defined their subordinate social role and status."). 
tice operates in that way or causes those kinds of subordinating harms, nor does it indicate how we are to ascertain the answers to these questions. ${ }^{93}$

So, to return again to Virginia, how would we go about applying the standard that opinion suggests? How can we determine whether a particular practice denies women "full citizenship stature" or "create[s] or perpetuate[s] the legal, social, and economic inferiority of women" ${ }^{94}$ In the remainder of this Article, I propose to try to give some content to the framework that Virginia outlines. More specifically, Part II will explore the potential usefulness of the historical record.

History is not the sole source that one could draw upon in considering how to flesh out Virginia's proposed standard. It is also not the case that a historical record can decisively indicate whether a particular practice currently operates to deny women equal citizenship and maintain their inferiority. Over time, practices can be reborn in important ways to serve new functions, accomplish new purposes, and play new roles.

But a historical record can usefully inform an inquiry into whether a particular practice deprives women of equal citizenship. Considering a practice at some distance from the present day can uncover and highlight issues that may be hidden or submerged in current discussions. It can illuminate areas of concern, suggest factors that might be relevant, and reveal ways in which a Court applying the Virginia framework should be paying attention. It can help us identify some of the questions that a reasonable decisionmaker implementing Virginia's standard should be asking in deciding whether a specific practice contributes to women's inequality.

93. The labor, controversy, and judgment involved in translating anti-subordination theory into a specific agenda for legal reform is one reason that the relatively small body of scholarship applying anti-subordination principles to particular practices has made some of the most persuasive contributions to the anti-subordination tradition. This body of work includes Richard Delgado, Charles Lawrence, and Mari Matsuda on hate speech, Catharine MacKinnon on sexual harassment, and Reva Siegel on abortion regulation. See Richard Delgado, Words that Wound: A Tort Action for Racial Insults, Epithets, and Name Calling, in Words that Wound: CRITICal Race THEory, AsSaultive SPEech, and THE First AMENDMENT 89, 94 (Mari J. Matsuda et al. eds., 1993); Lawrence, supra note 87, at 461-62, 464-65; Mari J. Matsuda, Public Response to Racist Speech: Considering the Victim's Story, 87 MICH. L. REV. 2320, 2336-39 (1989); MACKINNON, supra note 87, at 7, 9-10, 27, 51; Siegel, supra note 92 , at 370 . This work tends not to self-consciously reflect on the fact of its particularity. In other words, it tends not to explicitly analyze the fact that it is applying antisubordination principles to a particular practice, and that those principles might apply differently in other contexts. But this body of scholarship does attempt to confront the questions and gather the evidence involved in making the case for why, when, and how hate speech, sexual harassment, abortion regulation, or some other specific practice causes specific and identified subordinating injuries to specific and identified classes of people. 
With this in mind, Part II turns to a historical record to wrestle with what we would need to know in order to determine whether a practice deprives women of "full citizenship stature" or operates "to create or perpetuate the legal, social, and economic inferiority of women." ${ }^{\text {"S5 }}$ Since this project is importantly motivated by the Virginia case, it takes as its case study the practice (or set of practices) that is sex-segregated public education in the United States.

\section{SeX-Segregated Public Education: A CASE StUdy IN USING HISTORY TO INFORM AN INQUIRY INTO WHETHER A SPECIFIC PRACTICE DENIES WOMEN "FuLL CITIZENSHIP STATURE" OR MAINTAINS THEIR "LEGAL, SOCIAL, AND ECONOMIC INFERIORITY"}

The historical record of sex-segregated public education brings into focus a variety of factors, issues, and questions that a Court could usefully consider in determining the appropriate constitutional status of sex-segregated public education under Virginia's framework. In the process, this record also suggests that Virginia's "full citizenship" standard may ultimately challenge, unsettle, and undermine many of the foundational assumptions of the current sex discrimination jurisprudence, including some endorsed in Virginia itself. ${ }^{96}$

It is worth emphasizing again that this is not because the historical record decisively establishes how sex-segregated public education, or any other practice, presently operates or should currently be regulated. Indeed, one insight that the historical record of sex-segregated public education brings to light is that whether, when, why, and how a specific practice denies women "full citizenship stature" or "create[s] or perpetuate[s] the legal, social, and economic inferiority of women" can change over time. ${ }^{97}$ This possibility is not acknowledged in the Virginia opinion, which seems to envision the practices that maintain women's unequal status as more fixed and stable. But even a brief review of the historical record of sex-segregated public education demonstrates that a practice's role in promoting unequal citizenship and legalized inferiority can evolve and shift.

Initially, for instance, public jurisdictions used sex segregation to completely deny women and girls access to various levels of public education. The exclusion of female students from public primary schools was a common practice in colonial New England, ${ }^{98}$ and contin-

95. Id.

96. Id. at 532 .

97. Id. at 532,534 .

98. Walter Herbert Small's thorough survey of colonial New England found only a small handful of references indicating that girls were educated in town schools, alongside boys or 
ued in the nation's first years. ${ }^{99}$ In the first part of the nineteenth century, in turn, the jurisdictions at the forefront of public education systematically barred women from the new forms of secondary education that were becoming available to men. Boston, for example, established what most scholars consider to be the first public high school in the United States in $1821 .^{100}$ But it was only open to male students. ${ }^{101}$ The Central High School in Philadelphia, which became the nation's first public high school outside of Boston in 1836 and the future subject of the Vorchheimer case, similarly excluded women. ${ }^{102}$

Starting in the middle of the nineteenth century, though, the practice of sex-segregated public education changed in important ways. As the rise of the industrial era made literacy more important, more Americans came to believe that women's role required schooling consistent with their racial and economic status. A variety of jurisdictions in this period used sex-segregated education to expand women's inclusion and engagement in the public educational system. In the second half of the nineteenth century, for instance, a number of cities that had first opened secondary schools exclusively for men also created high

separately. Based on all the available evidence, he concluded that "girls were generally barred out." WALTER HERBERT SMALL, EARLY NEW ENGLAND SCHOOLS 275-77 (1914).

Farmington, Connecticut, for instance, voted in 1687 to allocate twenty pounds "for the maintenance of a school for the year ensuing, for the instruction of all such children as shall be sent to it, to learn to read and write the English tongue." Id. at 277. Some Farmington residents apparently objected to the linguistic imprecision, however, perhaps because some girls attempted to attend the town school. The town clarified its initial decision the next year, with a vote "'declar[ing] that all such is to be understood [as meaning] only male children that are through their horn book."' Id.

99. Northampton, Massachusetts, for example, excluded all female students from its public schools, a situation recorded in a rare lawsuit brought against the town in 1792. See The Early Schools, in CENTENNIAL HAMPSHIRE GAZETTE 12, 12 (Northampton, Hampshire Gazette 1886). As the Centennial edition of the Northampton Gazette would later recall, "the town was indicted and fined" for its refusal to admit girls to its public schools. Id. The legal basis for this court victory (like the identity of the plaintiffs) is unclear, as the court records for the judicial challenge apparently no longer exist. Whatever the grounds for the decision, though, the Gazette recounted that Northampton responded to the judicial judgment against the town in 1792 by voting, "'by a large majority,' to admit girls between the ages of 8 and 15 to the schools from May 1 to Oct. 31." Id; see also 2 JAMES RUSSELL TRUMBULL, HISTORY OF NORTHAMPTON MASSACHUSETTS, FROM ITS SETTLEMENT IN 1654, at 551-52 (1902) (quoting the report of the 1792 Northampton committee that recommended the establishment of some coeducational public schools). It is worth noting, however, that Northampton does not appear to have consistently abided by the legal judgment against it. According to the town's history, "[g]irls were not admitted to the town schools every year after permission was first granted. In 1799, the town refused to make any appropriation for schooling them." Id. at 585 .

100. See, e.g., EMIT DUNCAN GRIzZELL, ORIGIN AND DEVElopMENT OF THE High SCHOOL IN NEW ENGLAND BEFORE 1865, at 277 (1922); ALEXANDER JAMES INGLIS, THE RISE OF THE HIGH SCHOOL IN MASSACHUSETTS 15 (1911).

101. See INGLIS, supra note 100, at 16; SEMI-CENTENNIAL ANNIVERSARY OF THE ENGLISH HIGH SCHOOL 76-78 (Boston, Nathan Sawyer \& Son 1871).

102. See Vorchheimer v. Sch. Dist., 400 F. Supp. 326, 328 (E.D. Pa. 1975); supra text accompanying notes $40-43$. 
schools for female students. Boston established a public high school for women in $1854,{ }^{103}$ and Philadelphia opened a normal school for women in 1848 that became an academic high school in $1893 . .^{104}$ This movement, however, mostly included southern jurisdictions, such as Baltimore, ${ }^{105}$ Charleston, ${ }^{106}$ Louisville, ${ }^{107}$ and New

103. This school had opened in 1852 as a small two-year normal school for the training of grammar school teachers. See OLIVE B. WHITE, CENTENNIAL HISTORY OF THE GIRLS' HIGH SCHOOL OF BOSTON 9, 14-16 (1952); LUCY R. WOODS, A HISTORY OF THE GIRLS' HIGH SCHOOL OF BOSTON, 1852-1902, at 6 (1904); Girls in the Public Schools of Boston, 13 AM. J. EDUC. 243, 263-66 (1863). By 1853, however, women had secured twenty-seven hundred signatures on a petition demanding a High School for Girls in Boston. See HARRIOT K. HuNT, GLANCES AND Glimpses 309 (Boston, John P. Jewett.\& Co. 1856).

Boston had actually established an earlier High School for Girls in 1826. See Girls in the Public Schools of Boston, supra, at 246 (quoting the first catalogue of the High School for Girls). But the city closed this women's high school after only two years, citing specifically the tremendous demand for it. See id. at 247. As the Boston School Committee explained, young men attended Boston's English High School in order to prepare for "'professions and pursuits," so rigorous meritocractic selection was called for in order to identify the most promising male scholars. $I d$. at 250 (quoting report adopted at February 21, 1828 meeting of Boston School Committee). In contrast, the School Committee insisted that young women would have no professional use for their educations once they married, and concluded that singling out the most academically promising women would therefore be inconsistent with the purpose of the High School for Girls. See id. (quoting report adopted at February 21, 1828 meeting of Boston School Committee).

104. See.Vorchheimer, 400 F. Supp. at 328; RoBert WAynE Clark, THE Genesis of THE PHILADELPHIA HIGH SCHOOL FOR GIRLS 13, 25, 36, 90-92 (1938). For articles advocating the creation of a High School for Girls in Philadelphia, see Free Academy for Girls, 50 GODEY's LADY's BOOK 468, 468 (1855) ("When is the 'High School for Girls' to be established in Philadelphia?"); High Schools for Girls, 46 GODEY'S LADY's BOOK 176, 176 (1853) ("Philadelphia has one of the most flourishing High Schools for Boys in the United States.... Where is its twin seminary for the daughters of the people? Are these, the jewels of the State, the grace and glory of their homes, to be forgotten, and left in comparative ignorance, when the character, the destiny of the coming generation are to be in their keeping?"); Philadelphia High School for Girls, 48 GodEY's LADY's BOoK 464, 464 (1854) ("When is this institution to be opened? The High School for Boys has been sustained in the most liberal manner many years, and now a new and costly edifice for the school is nearly prepared. Will not the men of Philadelphia add beauty as well as strength to the recent act of 'Consolidation,' by founding a HIGH SCHOOL FOR GIRLS?").

105. Baltimore established a high school exclusively for white boys in 1839 , and founded two high schools for white girls in 1844. See Baltimore Public Schools, 13 COMMON SCH. J. 102, 103 (1851); A.D. Mayo, The Organization and Development of the American Common School in the Atlantic and Central States of the South, 1830 to 1860, in 1 REPORT OF THE COMMISSIONER OF EDUCATION FOR THE YEAR 1899-1900, at 427, 443 (1901). Before "1867 there was no provision for the public schooling of colored children." Id.

106. Charleston established a high school for white boys in 1839. See William M. Geer, The High School of Charleston: Ninety-eight Years of Service, 1 S. Ass'N Q. 385, 385-86 (1937). But it did not create a high school for white girls until 1858. See MARY TAYLOR, A HISTORY OF THE MEMMINGER NORMAL SCHOOL CHARLESTON, S.C. 1, 4, 7-8 (1941).

107. White men in Louisville, Kentucky had long had access to a "school known at different periods in its history as Jefferson Seminary, Louisville College, and the academic department of the University of Louisville." ALVIN FAYETTE LEWIS, HISTORY OF HIGHER EDUCATION IN KENTUCKY 348 (U.S. Bureau of Education, Circular of Information No. 3, Washington, Government Printing Office 1899). The city formally converted this school into a white male high school in 1851 , the same year the city provided by charter for a white female high school. See id, at 348-49. The school for white female students, however, did not actually open until 1856. See id. at 349; see also REPORT OF THE GIRLS HIGH SCHOOL OF 


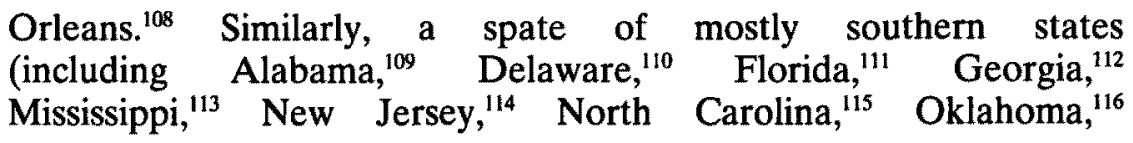

LOUISVILLE, KY. 2 (1916). Louisville also opened a Manual Training High School, exclusively for white male students, in 1892. See SIXTEENTH ANNUAL REPORT OF THE MANUAL TRAINING HIGH SCHOOL 9-10 (1908).

108. New Orleans opened a high school for white boys in 1845 , and a high school for white girls in 1847. See Elsa Louise Behrend, The New Orleans Public School System Since the Civil War 4-5 (1931) (unpublished M.A. thesis, Tulane University) (on file with author).

109. See An Act To create and establish an industrial school in the State of Alabama for white girls, $\$ 6,1893$ Ala. Acts 1002, 1004 (providing for "[t]he establishment and maintenance of a first-class industrial school for the education of white girls in the State of Alabama in industrial and scientific branches, at which said girls may acquire a thorough normal school education, together with a knowledge of kindergarten instruction and music; also a knowledge of telegraphy, type-writing, stenography, photography and phonography").

110. See An Act Providing for Securing the Site, Erecting, Equipping and Furnishing Buildings for a Women's College Affiliated with Delaware College, at Newark, Delaware, and to Provide the Method of Paying for the Same, ch. 124, \& 1, 27 Del. Laws 311, 311 (1913) (providing for "a Women's College affiliated with Delaware College, at Newark, Delaware").

111. See An Act to abolish the Florida Agricultural College, ch. $5384, \S \S 12,22,1905$ Fla. Laws ch. 13, 37, 45, 53 (establishing "The Florida Female College," for "[n]one but female white students," "to teach and instruct in all the higher branches of education, and in all the useful arts and sciences that may be necessary or appropriate to be taught in like institutions").

112. See An Act to establish a Normal and Industrial College as a branch of the State University, for the education of white girls; to appropriate money for the same, and for other purposes, $\$ \S 1,10,1889 \mathrm{Ga}$. Laws 10, 10, 13 (establishing "a college for the education of white girls, to be known as the "Georgia Normal and Industrial College" to teach such "practical industries as may tend to fit and prepare girls for occupations which are consistent with feminine refinement and modesty").

113. See An Act to create and establish an Industrial Institute in the State of Mississippi, and a College for the education of white girls in the arts and sciences, ch. $30, \$ \S 1,6,1884$ Miss. Laws 50, 50, 52 (establishing "the Mississippi Industrial Institute and College for the Education of White Girls of the State of Mississippi in the Arts and Sciences," to provide "a thorough normal school education, together with a knowledge of kindergarten instruction, also a knowledge of telegraphy, stenography and photography; also a knowledge of drawing, painting, designing, and engraving in their industrial application; also a knowledge of fancy, practical and general needle-work; and, also, a knowledge of bookkeeping").

114. On the founding of the New Jersey College for Women in 1918, see THE EARLY History of NEW JeRsey COLlege for WOMEN: PERSONAL RECOLlections by DEAN Douglass 5-14 (1928); Rutgers College, Meeting of the Trustees of Rutgers College in New Jersey 4 (Apr. 12, 1918) (on file with author; Rutgers University Libraries) ("Resolved that the Trustees of Rutgers College do establish a Woman's College as a department of the State University of New Jersey maintained by the Trustees.").

115. See An act to establish a normal and industrial school for white girls, ch. $139, \$ 1$, 5, 1891 N.C. Sess. Laws 126, 126-27 (establishing "an institution for the white race under the corporate name of "The Normal and Industrial School"' "to give to young women such education as shall fit them for teaching" and "to give instruction to young women in drawing, telegraphy, type-writing, stenography, and such other industrial arts as may be suitable to their sex and conducive to their support and usefulness").

116. See An Act To Establish An Industrial Institute And College For Girls In The State Of Oklahoma, And Providing For Its Location And Government, \$\$ 2-3, 13, 1908 Okla. Sess. Laws 614, 614-16 (establishing "the 'Oklahoma Industrial Institute and College 
South Carolina, ${ }^{117}$ and Texas) ${ }^{118}$ established public women's colleges in the late nineteenth and early twentieth centuries. If one were to evaluate whether, when, why, and how sex-segregated public education operated in the late nineteenth and early twentieth centuries to deny women "full citizenship stature," 119 the conclusions one would draw would have to differ, in at least some respects, from the assessments that one would make about the practice of sex-segregated public education as it existed a half century earlier.

Nevertheless, the historical record of sex-segregated public education can usefully inform an investigation into whether, when, why, and how sex-segregated public education currently functions to deprive women of "full citizenship" or maintain their "inferiority." 120 Let's examine that record to see how this can work.

\section{A. Different Populations of Women Are Not Necessarily Interchangeable in Considering What Denies Women "Full Citizenship" and Maintains Their "Inferiority"}

Virginia, following the Court's earlier sex discrimination cases, appears to assume that different populations of women are interchangeable for constitutional purposes. The Virginia opinion, like the one in Hogan before it, notes that the school it is reviewing was once racially segregated. ${ }^{21}$ But neither Virginia nor Hogan ever explores or men-

for Girls," open to "[a]ll white female citizens of Oklahoma between the ages of twelve (12) and thirty-five (35)," "to give instruction in industrial arts, the English language and the various branches of mathematical, physical, natural and economical sciences, with special reference to their application in the industries of life").

117. See An Act to Establish a Normal and Industrial College in the State of South Carolina for the Education of White Girls, $\$$ 1, 5, 1891 S.C. Acts 1102, 1102, 1104 (establishing "'The South Carolina Industrial and Winthrop Normal College"" "for the thorough education of the 'white girls' of South Carolina, the main objects of which shall be (1) to give to young women such education as shall fit them for teaching; (2) to give instruction to young women in ... such other industrial arts as may be suitable to their sex and conducive to their support and usefulness").

118. See An Act to create and establish an industrial institute and college in the State of Texas for the education of white girls in the arts and sciences, ch. 132, $\$ \$ 1,5,1901$ Tex. Gen. Laws 306, 306-07 (establishing "the 'Texas Industrial Institute and College for the Education of White Girls of the State of Texas in the Arts and Sciences," "at which such girls may acquire a literary education, together with a knowledge of kindergarten instruction; also a knowledge of telegraphy, stenography and photography; also a knowledge of drawing, painting, designing and engraving, in their industrial application; also a knowledge of general needle-work, including dressmaking; also a knowledge of bookkeeping; also a thorough knowledge of scientific and practical cooking, including a chemical study of food; also a knowledge of practical housekeeping").

119. United States v. Virginia, 518 U.S. 515, 532 (1996).

120. Id. at 532, 534 .

121. See id. at 546 n.16 ("VMI has successfully managed another notable change. The school admitted its first African-American cadets in 1968."); Mississippi Univ. for Women v. Hogan, 458 U.S. 718 . 719-20 (1982) ("In 1884, the Mississippi Legislature created the 
tions the possibility that a sex-segregated public school might inflict somewhat different injuries on white and African-American women, or that the practice of sex-segregated public education might be partially motivated or structured by concerns tied to race and class. In this regard, the opinions track much of the scholarly literature on sexsegregated public education, which has frequently overlooked or underemphasized the ways in which race and class have shaped sexsegregated public education in the United States. ${ }^{122}$

The historical record of sex-segregated public education reveals, however, that practices can deny "full citizenship stature," 23 and "cre-

Mississippi Industrial Institute and College for the Education of White Girls of the State of Mississippi, now the oldest state-supported all-female college in the United States."); id. at 727 n.13 ("Apparently, the impetus for founding MUW came not from a desire to provide women with advantages superior to those offered men, but rather from a desire to provide white women in Mississippi access to state-supported higher learning. In 1856, Sally Reneau began agitating for a college for white women.").

On the Mississippi University for Women's resistance to racial desegregation, see United States v. Fordice, 505 U.S. 717, 722 (1992) ("Despite this Court's decisions in Brown $I$ and Brown $I I$, Mississippi's policy of de jure segregation continued. The first black student was not admitted to the University of Mississippi until 1962, and then only by court order. For the next 12 years the segregated public university system in the State remained largely intact. Mississippi State University, Mississippi University for Women, University of Southern Mississippi, and Delta State University each admitted at least one black student during these years, but the student composition of these institutions was still almost completely white.") (citation omitted).

122. To take a very prominent example, M. Elizabeth Tidball's famous study of 1500 women listed in Who's Who of American Women compared the graduates of coeducational colleges and women's colleges from 1910 to 1960 . See M. Elizabeth Tidball, Perspective on Academic Women and Affirmative Action, 54 EDUC. REC. 130, 132 (1973). It found that the women's colleges produced approximately "two-fold" more women "achievers" per thousand women graduates per decade than the coeducational colleges. See id. Based on this data, Tidball concluded that "men students and women faculty emerge as primary determinants of the number of women achievers. The fact that the women's colleges have none of the former and more of the latter than coeducational institutions may largely explain their significantly greater contribution to the wider society of career-successful women during the past 50 years." Id. at 134. Tidball's study, however, did not control for either the class or the race of the female graduates.

Later work by Mary J. Oates and Susan Williamson found no difference between the achievement levels of women who graduated from small women's colleges in the 1930s and women who graduated from small coeducational colleges in that decade, once one removed the women who graduated from the most elite, and wealthy, private women's colleges of the era, the "Seven Sisters" colleges. See Mary J. Oates \& Susan Williamson, Women's Colleges and Women Achievers, 3 SiGNS 795, 799-800 (1978) ("The [Seven Sisters] produced achievers at the rate of sixty-one per 10,000 graduates during the decade of the 1930s. In sharp contrast, the small [non-Seven Sisters women's colleges] and small [coeducational colleges] each produced at a rate of eighteen achievers per 10,000 women graduates. The [Seven Sisters] rate was 3.4 times that of all other small colleges and four times that of all other institutions, regardless of size. With the exception of the $1940 \mathrm{~s}$, at no time do they account for fewer than half of women's-college achievers."). Oates and Williamson concluded that "[i]t is not sufficient to observe that [the Seven Sisters] colleges were more selective in admissions than the other women's colleges. Rather, it is our contention that the average socioeconomic level of the student body in these seven colleges may be even more critical in accounting for the differences, although selectivity does remain a factor." $I d$. at 803 .

123. Virginia, 518 U.S. at 532. 
ate or perpetuate ... legal, social, and economic inferiority," 124 for one group of women and not another, or can maintain the unequal status of different sets of women in different ways. In the case of public education, for example, race and sex segregation, as well as class stratification, have long been practically and symbolically intertwined, although the precise nature of the interactions has shifted over time.

Public school systems in the United States have not made uniform efforts to segregate the sexes. Until the Brown decision and its enforcement, sex-segregated public schools were also frequently racially segregated, especially in the South where sex-segregated public education was particularly concentrated. More specifically, many sexsegregated public schools were explicitly limited to whites, ${ }^{125}$ and only slightly less explicitly restricted to students from relatively privileged socioeconomic backgrounds. The Mississippi Industrial Institute and College, for example, was founded in 1884 to serve white women exclusively, and white ladies more precisely. The school, which would eventually become the subject of the Hogan decision, ${ }^{126}$ trained its students to be teachers and secretaries. But it also imparted skills, like "drawing, painting, designing, and engraving," that were sought in a specific class of comparatively affluent women. ${ }^{127}$ In contrast, the same southern states that most strongly supported the sex-based segregation of white students in the nineteenth and twentieth centuries almost always operated coeducational schools for African-Americans. ${ }^{128}$

124. Id. at 534 .

125. Through the middle of the twentieth century, for instance, Texas A\&M limited admission to students who were both white and male. See TEX. CONST. of 1876, art. VII, $\$ 7$ ("Separate schools shall be provided for the white and colored children, and impartial provision shall be made for both."); Davis Holds Texas A.\&M. Is Boys School, BRYAN DAILY EAGLE, Jan. 5, 1934, at 1, 4 (reporting opinion from the district court of Brazos County, Texas that upheld the exclusion of women from Texas A\&M); Texas Girls Are Denied Right To Enroll in A. \& M. College As Writ Is Refused By Court, Houston Post, Jan. 6, 1934, at 1,2 (reporting same decision). Similarly, Virginia maintained four public colleges by the end of the nineteenth century, all limited to white men: the University of Virginia, the Virginia Military Institute, the Virginia Polytechnic Institute, and William and Mary College. See The Co-Ordinate College-A Vital Matter, 10 VA. J. EduC. 410, 410 (1917). For more examples of white-only admissions policies in both men's and women's public schools, see supra notes $105-109,111-113,115-118,121$.

126. See An Act to create and establish an Industrial Institute in the State of Mississippi, and a College for the education of white girls in the arts and sciences, ch. 30, $\S 1,1884$ Miss. Laws 50, 50; Hogan, 458 U.S. at 719-20; EDWARD MAYES, HISTORY OF EDUCATION IN MISSISSIPPI 245-55 (U.S. Bureau of Education, Circular of Information No. 2, Washington, Government Printing Office 1899); supra text accompanying notes 47-49, 52-60.

127. An Act to create and establish an Industrial Institute in the State of Mississippi, and a College for the education of white girls in the arts and sciences $\$ 6$; see also statutes cited supra notes 109-118.

128. For example, the only public institution of higher learning open to AfricanAmerican students in Texas before 1947 was coeducational. See An Act to establish an Agricultural and Mechanical College of Texas, for the benefit of the colored youths and to make appropriations therefor, ch. 92, \&1,1876 Tex. Gen. Laws 136, 136 (establishing "an Agricultural and Mechanifal College fqr the benefit 985 the colored youths of this State"). 
Through this structure, sex-segregated public education became a means of recognizing and developing the race and class status of relatively privileged whites, while simultaneously emphasizing the degraded racial and economic status of African-Americans.

One thing this record helps us understand is why someone like Justice Powell might assume that the historical practice of sexsegregated public education has been benign and geared to the mutual benefit of both sexes. ${ }^{129}$ This vision is not an accurate description of the past. But the social power of this understanding of history probably reflects the fact that the practice of sex-segregated public education was a form of privilege for some women in some respects.

Stated more concretely, it seems clear that white women, especially elite white women, received various dignitary benefits from the practice of sex-segregated public education. Treatment as a lady implied a certain level of dignity. Like the notion that the home is the particular province of women, it was historically associated with a judgment that the women designated as ladies were to be accorded some respect in arenas considered domestic, such as courtship, home life, and child rearing. ${ }^{130}$ This is not to say that the practice of sex-segregated public

The Texas State University for Negroes, founded in 1947, also admitted both men and women. See An Act providing for the establishment, support, maintenance and direction of a University of the first class for the instruction and training of colored people of this state, to be known as "The Texas State University for Negroes," ch. $29, \$ 12,1947$ Tex. Gen. Laws 36, 40 ("The term 'qualified applicant' as used in this Act shall mean any colored person who meets the educational requirements for entrance to the same course or courses in the University of Texas or any of its branches. The term 'colored person' has the same meaning as contained in the provisions of the Texas Constitution requiring separate schools, ... towit: a negro or person of African descent.").

Similarly, the only form of public higher education open to blacks in Virginia through the first half of the twentieth century was a coeducational school, first called the Virginia Normal and Collegiate Institute and eventually renamed the Virginia State College for Negroes. See State Board of Education, Virginia Colleges: A Bulletin of INFORMATION ABOUT THE STATE COLLEges and THE COlleges UNDER PRIVATE CONTROL IN VIRGINIA 19 (1942). Louisville, Kentucky, in turn, operated sex-segregated high schools for its white students in the early twentieth century, but a coeducational high school for African-Americans. See Reports of the Louisville School Board for the Years 19011902 and 1902-1903, in CITY OF LOUISVILLE: ANNUAL REPORTS FOR THE FISCAL YEAR ENDING AUGUST 31, 1903, AND DECEMBER 31, 1903, at 240, 247 (1905); supra note 107; infra notes 156,164-166 and accompanying text.

Alcorn University, Mississippi's first public college for African-Americans, was limited to male students upon its founding in 1871, but became coeducational in 1895. See W. Milan Davis, Pushing forward: A History of AlCorn A. \& M. COllege and PORTRAITS OF SOME OF ITS SuCCESSFul GRAduATES 10-11, 27-29 (1938). In his 1895 report to the Alcorn trustees, which advocated establishing coeducation, President Thomas J. Calloway explained that he "had visited all the leading schools for colored people in Virginia, North and South Carolina, Georgia, Alabama, Tennessee, Kentucky and Mississippi, and [was] familiar with the workings of those in Louisiana, Texas, Arkansas and Missouri. Alcorn College [was] the only one, strictly speaking, that [was] for boys only." Id. at 25,27; see also infra text accompanying notes 134-135.

129. See supra text accompanying notes $52-54$.

130. Writing about a somewhat earlier era, Nancy Cott has nicely drawn out some of the ways in which what she galls "[t]he dqctrine of woman's sphere opened to women (reserved 
education caused white women to suffer no dignitary harm. We can note at the outset that the respect associated with ladyhood was quite different from, and not necessarily equivalent to, the respect granted to white men. But sex-segregated public education was nevertheless something of a mixed practice for white women. In contrast, sexsegregated public education inflicted unambiguous and particularly harsh dignitary harms on African-American women. Unlike white women, they were subject to the authoritatively enforced contention that they did not need or deserve to be treated like ladies, that because of their race they were not entitled to even the modicum of respect otherwise associated with their sex..$^{131}$

Similarly, if one considers the practice of sex-segregated public education from the standpoint of material injury, women's public schools gave many of their students more access to public education than they had had before. Here too, moreover, the material harm that women suffered as a result of their exclusion from the public schools reserved for white men differed dramatically for white and black women, even if neither group had access to the educational institutions where, as we will see,,$^{132}$ the social capital most associated with economic and political success was distributed. Consider Mississippi's system of higher education again. The Mississippi Industrial Institute and College, discussed more below, ${ }^{133}$ trained white women to be ladies. Alcorn University of Mississippi, founded in 1871 as the state's first public college open to African-Americans, ${ }^{134}$ trained its students to be farmers. ${ }^{135}$

for them) the avenues of domestic influence, religious morality, and child nurture." NANCY F. COTT, THE BONDS OF WOMANHOOD: "WOMAN'S SPHERE" IN NEW ENGLAND, 17801835 , at 200 (2d ed. 1997).

131. For an excellent account of black women's efforts in the second half of the nineteenth century and the beginning of the twentieth to win admission to the cars that railroads reserved for "ladies," see Barbara Y. Welke, When All the Women Were White, and All the Blacks Were Men: Gender, Class, Race, and the Road to Plessy, 1855-1914, 13 LAW \& HIST. REV. 261, 276 (1995) ("Regulations barring people of color from ladies' accommodations and assigning women and men of color alike to smoking cars reflected the assumption 'that all the women were white, and all the blacks were men.' This assumption denied people of color the right so fundamental to defining class status in nineteenth-century America, that is, the right of women of color to be recognized as ladies. In marked contrast to the accepted rule for first-class white travel, there was no attempt to provide women of color traveling first-class separate, superior facilities.").

132. See infra text accompanying notes 183-192.

133. See infra text accompanying notes $168-169$.

134. See An Act to establish and maintain Alcorn University of Mississippi, and for other purposes, ch. 327, $\$ 4,1871$ Miss. Laws 716,717 ; DAVIS, supra note 128 , at 10-11; supra note 128 .

135. See An Act to establish and organize Agricultural and Mechanical Colleges, and to regulate the government of the same, ch. 19, $\$ 1,1878$ Miss. Laws 118,119 ("Be it enacted by the Legislature of the State of Mississippi, That the institution known as the Alcorn University, is hereby established as, and declared to be an agricultural college for the educa- 
Once Brown was decided and enforced, the connection between race and sex segregation in public education shifted, but some jurisdictions still used the practice of sex segregation to express and enforce a (gendered) message of white supremacy and African-American inferiority. In the years after Brown, a number of the school districts ordered to end their practice of racial segregation went to court to argue that they should be permitted to establish sex segregation in their schools instead. Public school officials argued in these suits that instituting sex segregation would have the immediate effect of reshuffling white and black students into two groups of approximately equal racial composition. A school district with a white and a black high school, for example, could smoothly transform its two schools into one for girls and one for boys, both of which would be racially integrated. ${ }^{136}$

This sex-based reshuffling also had the advantage (from the school districts' perspective) of ensuring that white girls could remain separated from black boys despite the abolition of legalized racial segregation. Maintaining this separation had been one of the primary historical justifications for racial segregation. ${ }^{137}$ It functioned as a way of degrading African-Americans: Legal authorities sought to shield white women from black men, but never expressed concern about protecting black women from white men. ${ }^{138}$ At the same time, it also served to simultaneously honor white women and justify their confinement. ${ }^{139}$

tion of the colored youth of the State, and to be hereafter known as the Alcorn Agricultural and Mechanical College of the State of Mississippi.").

136. See United States v. Hinds County Sch. Bd., No. 3983, slip op. at 2 (S.D. Miss. July 14, 1970) (findings of fact and recommendations), ruling deferred, Nos. 28030 \& 28042, slip op. at 2 (5th Cir. Aug. 6, 1970) (per curiam) (permitting sex segregation to continue); Moore v. Tangipahoa Parish Sch. Bd., 304 F. Supp. 244, 249 (E.D. La. 1969), appeal dismissed at request of all parties, 421 F.2d 1407, 1407 (5th Cir. 1969) (per curiam); Smith v. St. Tammany Parish Sch. Bd., 302 F. Supp. 106, 108 (E.D. La. 1969), amended on other grounds, 316 F, Supp. 1174 (E.D. La. 1970); Banks v. St. James Parish Sch. Bd., No. 16173, slip op. at 1-3 (E.D. La. June 9, 1969).

137. On the central role that white America's concerns about preventing sexual contact between white women and black men played in promoting racial segregation in the United States, see, for example, MARTHA HODES, WhITE WOMEN, BLACK MEN: ILliCIT SEX IN THE NINETEENTH-CENTURY SOUTH 1-6 (1997); LEON F. LITWACK, BEEN IN THE STORM SO LONG: THE AFTERMATH OF SLAVERY 265 (1979) ("Behind every discussion and skirmish involving racial separation lurked the specter of unrestrained black lust and sexuality, with that most feared of consequences-racial amalgamation or, as it was now popularly called, miscegenation."); Jill Elaine Hasday, Federalism and the Family Reconstructed, 45 UCLA L. REV, 1297, 1343-53, 1365-70 (1998).

138. See, e.g., Victoria E. BYNum, UnRuly WOMEN: THE Politics of Social AND SEXUAL CONTROL IN THE OLD SOUTH S, 9, 96-98 (1992); JACQUELINE JONES, LABOR OF LOVE, LABOR OF SORROW: BLACK WOMEN, WORK, AND THE FAMILY FROM SLAVERY TO THE PRESENT 149-50 (1985); Evelyn Brooks Higginbotham, African-American Women's History and the Metalanguage of Race, 17 SIGNS 251, 262-66 (1992); Eva Saks, Representing Miscegenation Law, RARITAN, Fall 1988, at 39, 43.

139. See, e.g, CATHERINE Clinton, THE Plantation Mistress: Woman's World IN THE OLD SOUTH 87-89, 209-10 (1982); ELLIZABETH FOX-GENOVESE, WITHIN THE 
In the years after Brown was decided, white America's obsessive fears about interracial sex and marriage (often pejoratively called miscegenation $)^{140}$ only intensified. ${ }^{141}$ Yet the courts reviewing the schools' remedial strategies-after Brown but before the application of heightened scrutiny to sex-based state action-routinely upheld sexsegregated public education, at the very same moment that they were striking down racial segregation in public schools. ${ }^{142}$ They did not see, or they did not acknowledge, the connection between race and sex.

Plantation Household: Black AND WhItE WOMEN OF THE OLd SOUTH 235-36, 241 (1988); GlendA ElIZABETH GILMORE, GENDER AND JIM CROW: WOMEN AND THE POLITICS OF WHITE SUPREMACY IN NORTH CAROLINA, 1896-1920, at 72, 82-83, 96 (1996); JaCQuelyn Dowd Hall, Revolt Against Chivalry: Jessie Daniel Ames aNd the WOMEN'S CAMPAIGN AGAINST LYNCHING 149-57 (rev. ed. 1993),

140. For a discussion of the historical origins of this term, see Hasday, supra note 137 , at 1343 n.166.

141. James Jackson Kilpatrick, a white southerner, offered a typical example of this mode of reasoning in 1962. As he explained:

The arguments of anthropology are of interest to the South, and I would not wish to leave any impression that would minimize their importance; the fear of ultimate racial interbreeding, encouraged by prospective generations of desegregated and integrated school systems, is a very real fear in the South and not an imagined one. If these Negro characteristics are innate, the white Southerner sees nothing but disaster to his race in risking an accelerated intermingling of blood lines. And even if these Negro characteristics are not innate, the white Southerner wants no intimate association with them anyhow. And he is determined not to let his children be guinea pigs for any man's social experiment.

James JaCkSON KILPATRICK, THE SOUTHERN CASE FOR SCHOOL SEgregation 72 (1962); see also O.R. WILlIAMS, SR., SEGREGATION AND COMMON SENSE 166 (1961) ("The Supreme Court's school and other desegregation decisions are forcing the white people of this Nation to associate with the Negro race. Close association with each other-especially while young-is all that is necessary to mongrelize the races."); WILLIAM D. WORKMAN, JR., THE CASE FOR THE SOUTH 212 (1960) ("[The white southerner] finds complete repugnance in the idea of any mixing of the races, and that is one of his fundamental objections to racial integration in the public schools."). For contemporary assessments of the political landscape in the years after Brown, see ALEXANDER M. BICKEL, THE LEAST DANGEROUS BRANCH: THE SUPREME COURT AT THE BAR OF POLITICS 174 (1962) ("[W] hen the Court had just pronounced its new integration principle,... it was subject to scurrilous attack by men who predicted that integration of the schools would lead directly to 'mongrelization of the race' and that this was the result the Court had really willed...."); WALTER F. MURPHY, ELEMENTS OF JUDICIAL STRATEGY 193 (1964) ("[l]t is even more clear that racial intermarriage-'mongrelization'-has been the great bête noire of white southern society and one of the chief reasons behind the resistance to school integration."); Louis $\mathrm{H}$. Pollak, The Supreme Court and the States: Reflections on Boynton v. Virginia, 49 CAL. L. REV. 15, $45 \mathrm{n} .79$ (1961) ("[T]he constitutional problem presented in Naim v. Naim [an interracial marriage case] is widely thought to be so sensitive as to make hazardous any generalizations based on this unique history."); Andrew L. Kaufman, Book Review, 7 NAT. L.F. 154, 155 (1962) ("We may assume that the Court would not have taken this extraordinary course of action had the main issue in the case [Naim v. Naim] not been the explosive issue of miscegenation.").

142. See United States v. Hinds County Sch. Bd., No. 3983, slip op. at 7 (S.D. Miss. July 14,1970 ) (findings of fact and recommendations) ("[T]he Court finds that defendants have met their burden of showing that the separation by sex plan stems from sound educational purposes as distinguished from racially discriminatory purposes."), ruling deferred, Nos. 28030 \& 28042, slip op. at 2 (5th Cir. Aug. 6, 1970) (per curiam) (permitting sex segregation to continue); Moore v. Tangipahoa Parish Sch. Bd., 304 F. Supp. 244, 249 (E.D. La. 1969) ("The court recognizes that the trend in modern education is in the other direction. But edu- 
In sum, the question of whether, when, why, and how a practice denies women "full citizenship stature," ate[s] the legal, social, and economic inferiority of women," 144 can easily have different answers for different populations of women. Class and especially race have long been embedded in the practice of sexsegregated public education, for instance. Indeed, in light of this history, it should not be surprising to learn that many of the communities that have recently been most interested in establishing sex segregation

cational decisions are for the School Board alone. Many school districts in this country have long operated separate schools for boys and girls. This educational philosophy is also practiced in many colleges and universities although their number is decreasing every year."), appeal dismissed at request of all parties, 421 F.2d 1407, 1407 (5th Cir. 1969) (per curiam); Smith v. St. Tammany Parish Sch. Bd., 302 F. Supp. 106, 108 (E.D. La. 1969) ("The school board offers this proposal only as a transitory measure designed to ease the conversion to a unitary system. For the reasons set forth in Moore v. Tangipahoa Parish School Board, supra, the Court will approve this proposal for the 1969-70 school year."), amended on other grounds, 316 F. Supp. 1174 (E.D. La. 1970); Banks v. St. James Parish Sch. Bd., No. 16173, slip op, at 1-3 (E.D. La. June 9, 1969) ("ORDERED, ADJUDGED AND DECREED that defendant St. James Parish School Board implement and effectuate for the 1969-70 school year its plan to effect a unitary, non racial school system for St. James Parish. ... All boys, grades 1-12, from Central and Romeville will attend Central School. ... All girls, grades 112, from Central and Romeville will attend Romeville School.... All girls grades 5-12, formerly attending St. James High School, Magnolia High School, Magnolia Elementary, and Consolidated Elementary will attend the St. James High School. ... All boys, grades 5-12, formerly attending St. James High School, Magnolia Elementary, Consolidated Elementary will attend the Magnolia High School.").

After the Supreme Court had applied heightened scrutiny to sex-based classifications, the Fifth Circuit did hold that a school district could not impose mandatory sex segregation on its entire school system as a means of remedying its former practice of racial segregation. See United States v. Hinds County Sch. Bd., 560 F.2d 619,620-25 \& n.7 (5th Cir. 1977). This decision, however, ultimately relied on new statutory rather than new constitutional arguments. It held that the school district's remedial strategy violated the Equal Educational Opportunities Act of 1974, Pub. L. No. 93-380, 88 Stat. 514, which prohibited states from denying equal educational opportunity on the basis of sex, see $560 \mathrm{~F} .2 \mathrm{~d}$ at $620-25$ \& n.7. In the course of this litigation, which forced the school district to defend its use of sex segregation, the district alluded to community concerns about contact between white girls and black boys, arguing "that it should be permitted to continue its present modified plan because it fears that whites will leave the public school system if sex-desegregation is implemented." Id. at 624. The Fifth Circuit held that this was "an impermissible basis for refusing to comply with the statutorily mandated scheme." Id.; see also Helen Dewar, Blacks Boycott SexSegregated Schools, WASH. POST, Sept. 4, 1977, at A32, A32 (noting that, "[a]ccording to Robert Wilson Jr., the one black member of the school board [at issue in this case], the [school district's sex segregation] plan was drafted in 1969 to 'prevent black males and white females from having any contact' in the classrooms"); id. (reporting that black students in this school district had begun boycotting their classes in August 1977 to protest the sex segregation); Merrill Sheils, Segregation by Sex, NEwSWEEK, Sept. 19, 1977, at 97, 97 ("'They never had any idea of changing the situation,' says Robert Wilson, the only black member of the school board. 'It has always been a racial issue. The idea is to keep the black boys from having any contact with the white girls-pure and simple."); id. ("Bernard Dunaway, the board's president, indicates that there is some truth to Robert Wilson's charge that whites prefer to keep the sexes separate for racial reasons. Boys and girls could attend school together before 1969, he explains, because 'we had one school for whites and another school for coloreds." ).

143. United States v. Virginia, 518 U.S. 515, 532 (1996).

144. Id. at 534 
in their public schools are much less privileged than the elite groups that historically dominated single-sex public education. For many people, the practice of sex-segregated public education continues to have elite connotations, and the contemporary notion that sex segregation will help elevate communities traditionally denied elite status and privilege builds on this line of thought. In 1991, for example, Detroit sought to open three all-male academies for boys in elementary school and junior high. ${ }^{145}$ The city argued that the schools would be manifestations of racial pride and sites of heightened opportunity in a predominately African-American and poor jurisdiction. ${ }^{146}$ These sorts of aspirations, of course, still leave plenty of room for the possibility that Detroit's single-sex schools would have contributed to women's inequality, and in fact a federal court barred Detroit from opening the schools in sex-segregated form long before Virginia was decided. ${ }^{147}$ The historical record suggests, however, that in considering

145. See Garrett v. Bd. of Educ. of the Sch. Dist. of Detroit, 775 F. Supp. 1004, 1005-06 (E.D. Mich. 1991).

146. See id. at 1006 ("The Academies offer special programs including a class entitled 'Rites of Passage', an Afrocentric (Pluralistic) curriculum, futuristic lessons in preparation for 21 st century careers, an emphasis on male responsibility, mentors, Saturday classes, individualized counseling, extended classroom hours, and student uniforms.").

In 1996, Governor Pete Wilson of California endorsed sex-segregated public education in terms resonant with the Detroit debate. As he explained in his State of the State Address that year:

Some cities around the nation have found success with all-male classrooms for at-risk boys.

There, strong male teachers serve as an alternative to gang leaders.

So I propose establishing all-male Empowerment Academies as magnet schools. There boys can find the discipline and role models they'll need to escape a life on the streets.

In the same way, young girls and their parents should have the option of all-female schools.

I'd especially like to see such a school offer girls the opportunity to concentrate on math and science.

3 Journal of the Assembly: Legislature of the State of California, 1995-96 REGULAR SESSION, at 4311 (1996) (statement of Gov. Wilson).

147. See Garrett, 775 F. Supp. at 1014. As the court explained:

In Mississippi v. Hogan, the Supreme Court held that exclusion of an individual from a publicly-funded school because of his or her sex violates the Equal Protection Clause of the Fourteenth Amendment, unless the defendant can show the sex-based "classification serves 'important governmental objectives and that the discriminatory means employed" are "substantially related to the achievement of those objectives."

....

None of the[] findings meet the defendant's burden of showing how the exclusion of females from the Academies is necessary to combat unemployment, dropout and homicide rates among urban males. There is no evidence that the educational system is failing urban males because females attend schools with males. In fact, the educational system is also failing females. Thus, the Court concludes the application of the second prong of the Hogan test to the facts at hand, makes it likely that the plaintiffs will succeed on a constitutional argument.

Id. at 1006, 1008 (citations omitted).

After this legal defeat, the Detroit school board agreed to admit female students to the three schools at issue in Garrett. See Clifford WATSON \& GenEva SMITHERman, EDUCATING AFRICAN AMERICAN MALES: DETROIT'S MALCOLM X ACADEMY SOLUTION 49 (1996); Detroit Boqrd Agrees To Let Girls Attend Male Only Academies, SCH. L. NEWS, 
the appropriate constitutional status of schools like this under Virginia's framework, a Court could usefully explore the possibility that whether, when, why, and how a sex-segregated public school deprives women of "full citizenship stature" may differ depending on the race, class, or other characteristics of the women at issue. ${ }^{148}$

\section{B. Separation Is Not the Only Mechanism for Denying Women "Full Citizenship" and Maintaining Their "Inferiority": The Historical Overlap Between Sex-Segregated and Coeducational Public Education}

The historical record of sex-segregated (and coeducational) public education also reveals that separation of the sexes is not the only mechanism through which women's "full citizenship" can be denied and their "inferiority" maintained. ${ }^{149}$ Currently, the sex discrimination jurisprudence, even in Virginia, focuses narrowly on separation. State action, like sex-segregated public education, that openly distinguishes or divides men and women is automatically subject to heightened scrutiny under the Equal Protection Clause. But facially neutral state action, like coeducational public education, is subject to heightened scrutiny only if the plaintiff can meet the extraordinarily difficult burden of demonstrating the equivalent of official malice: "that the decisionmaker ... selected or reaffirmed a particular course of action at least in part 'because of,' not merely 'in spite of,' its adverse effects upon" women or men. ${ }^{150}$ This rule all but ignores coeducational public schools as potential sources of women's inequality, and appears to assume that single-sex and coeducational public education are vastly different.

Aug. 29, 1991, at 5, 5; Laurel Shaper Walters, The Plight of Black Male Schools, CHRISTIAN SCI. MONITOR, Sept. 9, 1991, at 8,8. These schools have pursued an Afrocentric curriculum. See.WATSON \& SMITHERMAN, supra, at 55 ("The mission of the Malcolm X Academy grows out of its grounding in the pedagogy that has come to be known as 'African Immersion,' or "Afrocentricity."'); Kevin Bushweller, Separate by Choice, AM. SCH. BOARD J., Oct. 1996, at 34, 36 ("In the classroom [at Detroit's Malcolm X Academy], a red, green, and black flag of African-American nationalism serves as yet another reminder of the intensely racial focus of this school."). There is also some evidence that the schools' primary focus remains on male students. See WATSON \& SMITHERMAN, supra, at 24 ("Despite Judge Woods' ruling, today in 1994, the Detroit Public Schools' original 'Male Academy' concept continues virtually in full force. All three of Detroit's first African-Centered Academies have annually had a student population that is $90 \%$ or more Black male."); Bushweller, supra, at 34 ("Even though 15 percent of the students [at Detroit's Malcolm X Academy] are now girls, the school's primary mission remains helping young black males, says the school's principal, Clifford Watson.").

148. Virginia, 518 U.S. at 532.

149. Id. at 532,534 .

150. Pers. Adm'r v. Feeney, 442 U.S. 256, 279 (1979) (rejecting equal protection challenge to Massachusetts veterans' preference statute because "nothing in the record demonstrates that this preference for veterans was originally devised or subsequently re-enacted because it would accomplish the collateral goal of keeping women in a stereotypic and predefined place in the Massachusetts Civil Service"). 
The focus on separation in the sex discrimination jurisprudence may reflect that case law's frequent reliance on analogies to race discrimination. ${ }^{151}$ The mechanism of separation has figured very prominently in the history of race in the United States. The very fact that whites and blacks were kept apart, in school and especially in relations of intimacy, appears to have been among the most important means through which white supremacy was expressed and enforced. Recall, for instance, the many school districts that were convinced that one of the most effective ways they could preserve racial hierarchy after Brown was by separating black boys from white girls. ${ }^{152}$ This is not to say that white supremacy has always been maintained through the mechanism of separation. One important historical expression of white privilege, for instance, was the legal protection that white men enjoyed in seeking sexual access to black women. ${ }^{153}$ But in general, the history of race discrimination often focuses our attention on separation as the means by which unequal citizenship and legalized inferiority can be sustained.

The history of sex-segregated and coeducational public education, however, helps us see another powerful mechanism by which "full citizenship" can be denied and "legal, social, and economic inferiority" preserved. ${ }^{154}$ This mechanism might be called "sex role confinement." One common feature of the practice of sex-segregated public education through at least the mid-part of the twentieth century, one way it functioned to deny equal status to even the elite white women most privileged by the system, was by steering women toward marriage, motherhood, and a small number of poorly compensated jobs, and leaving them without the resources to make any other choices. This had dignitary consequences; it was premised on the view that women were not suited to assume a prominent part in the nation's public or economic life. It also caused women to suffer real material harm by depriving them of the training and connections that they needed to pursue such opportunities.

This role confinement, however, did not depend on separation. In fact, it was evident in approximately equal degree in the coeducational public schools of the period. Coeducational public schools brought the sexes together, but they maintained role differentiation and confinement and a focus on educating women for marriage and maternity. Sex-segregated public schools, in turn, separated students by sex, yet always operated on the premise that men's and women's lives were intimately intertwined.

151. See supra text accompanying notes 27-33.

152. See supra text accompanying notes $136-142$.

153. See supra text accompanying note 138.

154. Virginia, 518 U.S. at $532,534$. 
This feature of the historical record can inform an inquiry into the appropriate constitutional regulation of sex-segregated public education under Virginia's framework in at least three ways. First, this record suggests that it would be wise for a Court deciding whether to absolutely prohibit sex-segregated public schooling-a question the Court has been unable to resolve-to compare the practice of sexsegregated public education to that of coeducational public education. Presumably, a Court would be unwilling to find coeducational public schooling categorically unconstitutional. But as we will discover, the historical record reveals that differences of form like that between sexsegregated and coeducational public education can actually prove relatively unimportant in terms of their substantive impact on women's status. If the two forms of public education are operating with equal effect to maintain women's unequal status, moreover, it is difficult to see why a constitutional jurisprudence determined to protect women's equal citizenship would want to draw such an absolute line based on the form of public education, or how prohibiting all single-sex public schools and having all public school students attend coeducational institutions would further women's "full citizenship stature" or combat their "inferiority." 155 At the least, the case would need to be made.

Second, this record suggests that if sex-segregated public education is not found categorically unconstitutional under Virginia's framework, a Court deciding what constitutional regulations would best prevent single-sex public schools from operating to deny women equal status should consider the potential problem of role confinement. Requiring single-sex public schools to comply with separate but equal standards, moreover, may not necessarily be sufficient to counter this problem. Women's public schools, for example, have historically been underfunded compared to men's public schools. ${ }^{156}$ But it is not at all clear what equal funding would have done to stop the system of sexsegregated public education from steering women toward marriage and maternity and away from any alternate or additional life paths. Indeed, as we will see, the history of coeducational public education vividly illustrates that this kind of role confinement can flourish even in schools where female and male students officially have access to the same resources and the same curriculum.

155. Id.

156. In the 1901-1902 school year, for example, Louisville, Kentucky devoted more money to its white high school students than it spent on the Central Colored High School, which was coeducational and received $\$ 41.35$ per student. See Reports of the Louisville School Board for the Years 1901-1902 and 1902-1903, supra note 128, at 247. But the city also spent much more on the high schools for white boys $(\$ 99.42$ per student at the Manual Training High School and $\$ 71.03$ per student at the Male High School), than it spent on the high school for white girls (\$41.75 per student at the Female High School). See id. 
Third, this historical record suggests that a Court determined to safeguard women's "full citizenship" and fight their "inferiority" would be well-advised to focus much more constitutional scrutiny on coeducational public schools directly, examining them as potential sources of women's unequal status that may require more regulation for that reason. ${ }^{157}$ This last point is one that the Court may be especially unlikely to pursue. Virginia, after all, expresses no willingness to extend its reasoning to facially neutral state action. But the historical record explored here could also inform a legislative inquiry into how best to regulate coeducational public education so that it does not deprive women of "full citizenship stature" or "create or perpetuate the legal, social, and economic inferiority of women." 158

In Title IX of the Education Amendments of 1972, for example, Congress prohibited schools that receive federal funding from discriminating based on sex. ${ }^{159}$ This statute provides Congress with a relatively straightforward means of reaching a vast array of institutionssex-segregated and coeducational. As it now stands, Title IX's only relationship to history appears in a provision that privileges sexsegregated public colleges if they participated in the historical practice of sex segregation. Title IX denies funding to sex-segregated vocational schools, professional schools, graduate schools, and public colleges. ${ }^{160}$ But it permits funding to go to sex-segregated public colleges that have "traditionally and continually" excluded students of one sex. ${ }^{161}$ It is not clear why a statute concerned with combating sex discrimination should favor public colleges that have long been sexsegregated; the historical practice of sex-segregated public education in the United States was entangled in the maintenance of women's unequal citizenship. Yet the historical record does suggest that Congress's concern under Title IX could usefully extend beyond the question of sex segregation. Most notably, Congress could usefully devote particular attention to the potential problem (in both coeducational and single-sex public schools) of role confinement.

Let's examine the record.

The practice of sex-segregated public education as it existed in the United States through at least the middle of the twentieth century was systematically structured to direct women to marriage, motherhood, and a narrow range of low-wage, low-status market work, and to re-

157. Virginia, 518 U.S. at 532,534 .

158. Id.

159. See Education Amendments of 1972 , Pub. L. No. $92-318, \$ 901$ (a), 86 Stat. 235,373 (codified at 20 U.S.C. $\$ 1681$ (a) (2000)).

160. See id. $\$ 901(a)(1)$.

161. Id. $\$ 901(\mathrm{a})(5)$. 
strict women's opportunities for prominent participation in economic or political affairs. This was accomplished in several different ways.

Some of the strategies were located in the women's public schools. A number of these schools were designed to prepare women for female-dominated employment characterized by poor pay and little chance of advancement. The women's public high schools in Boston and Philadelphia, ${ }^{162}$ for instance, trained women for public school teaching, a job category that was becoming increasingly occupied by women as its wages and status declined. ${ }^{163}$ Other institutions trained their students for traditionally female jobs associated with even less money and prestige. The public high school for white women in Louisville, Kentucky, for example, offered its students a class "in Vocational Cooking," "'designed to prepare a girl for lunch-room management, catering, etc."'164

162. See supra notes $103-104$ and accompanying text.

163. In 1890 , women constituted $65.5 \%$ of all teachers in the public elementary and high schools of the United States. This figure rose to $70.1 \%$ in $1900,78.9 \%$ in 1910 , and $85.9 \%$ in 1920. See Frank M. PhILlips, U.S. DeP'T OF THE INTERIOR, BUll. No. 38, STATISTICAL SURVEY OF EDUCATION, 1921-1922, at 4 tbl.5 (1925). On the almost universal practice of paying women teachers much less than their male counterparts, see, for example, JOEL Perlmann \& Robert A. MARgo, WOMEn's Work?: AMERICAN SCHOOlTEACHERS, 1650-1920, at 33 (2001) ("In New York state, in the mid-1840s, women's wages averaged $\$ 5.55$ in the summer session and $\$ 6.98$ in the winter session, while men received $\$ 13.61$ and $\$ 14.06$ respectively, producing female-to-male wage ratios of 0.425 for the summer and 0.496 for the winter session."); id. at 116, 117 tbl.5.1 ("We have ... collected teacher lists from three cities: Grand Rapids, Michigan [from 1880 to 1903]; Portland, Oregon [from 1878 to 1906]; and Paterson, New Jersey [from 1875 to 1910]. . . . The lowest ratio of female-to-male salaries occurred in Paterson: there female personnel were paid, on average, 42 cents for every dollar earned by male personnel. The salary ratio was a bit higher in Grand Rapids $(0.47)$ and significantly greater in Portland (0.55) ...."); Horace Mann, Eleventh Annual Report of the Secretary of the Board of Education, in ELEVENTH ANNUAL REPORT OF THE BOARD OF EDUCATION, TOGETHER WITH THE ELEVENTH ANNUAL REPORT OF THE SECRETARY OF THE BOARD 21, 26 (Boston, Dutton \& Wentworth 1848) ("Now, the average wages of male teachers [in Massachusetts], last year, inclusive of their board, was $\$ 3246$, and the average wages of female teachers, also inclusive of board, was $\$ 1360 \ldots$. Such is the economy of employing female teachers, whom the Normal Schools have done so much, and are capable of doing so much more, to qualify."); Keith E. Melder, Woman's High Calling: The Teaching Profession in America, 1830-1860, 13 AM. STUD. 19, 22 (1972) ("Connecticut in $1838 \ldots$ paid men exclusive of board $\$ 14.50$ per month, women $\$ 5.75$. In Ashtabula County, Ohio, the average male wage was recorded as $\$ 14$ per month, while females took home \$1.25 each week. In the same year Massachusetts school returns indicated ... an average salary of $\$ 23.10$ a month for men, $\$ 6.49$ for women, excluding board. Pennsylvania ... recorded wages of $\$ 18.50$ per month for males, $\$ 11.30$ for females."); Jo Anne Preston, Feminization of an Occupation: Teaching Becomes Women's Work in Nineteenth-Century New England 36 (1982) (unpublished Ph.D. dissertation, Brandeis University) (on file with author) ("The average female summer wages for ten selected Massachusetts towns [in 18331834] ... were one-third to one-half of the average male wages. Although there existed substantial differences in wage ratios between towns, the women's average wage was never more than $50 \%$ of the male average in any particular town.").

164. Winifred Richmond, Present Practices and Tendencies in the Secondary Education of Girls, 23 PEDAGOGICAL SEMINARY 184, 187 (1916) (quoting "[a] recent letter from the principal"); see also Dora Wells, The Lucy Flower Technical High School, 22 SCH. REV. 611, 611, 614 (1914) ("If a girl [at the LufX K. Flower Technigal High School for girls in Chicago] 
Sometimes, moreover, women's public schools just trained women for marriage itself. Louisville's Female High School, for instance, did not offer the college preparatory classes available to the city's white male high school students. ${ }^{165}$ But it did supplement its class in vocational cooking with courses in household cooking, drawing, sewing, and millinery. ${ }^{166}$. Similarly, the Board of Commissioners for the public schools of Baltimore provided no college preparation at its high schools for white girls. As it explained, these female students were "in preparation for a different sphere of life," in which "[t]he circle of their operations" would "be circumscribed by the domestic relations," so that women remained outside "the arena of public action" and "in the quiet seclusion of home." 167 The president of the Mississippi Industrial Institute and College described his institution in related terms in 1887 , reporting that the school was "'not teaching woman to demand the 'rights' of men nor to invade the sphere of men." 168 Instead, the women's college was training its female students " for the ways of modest usefulness, for works of true benevolence," which would invest them "'with that true womanly character and those beautiful Christian graces that constitute [woman] the charm of social life and the queen of home." 169 The chairman of the Board of Trustees for the Winthrop Normal and Industrial College, ${ }^{170}$ a public school for

finds that her interest lies in cookery she may fit herself to assist in managing a lunchroom or an institutional kitchen or may make a beginning at general catering.").

165. See LEWIS, supra note 107, at 349 ("The course of the [female high] school is very similar to that of the male high school, but substitutes for Greek something in the way of what is usually denominated ornamental education."); see also REPORT OF THE MALE HIGH SCHOOL LOUISVILLE, KY. FOR THE SCHOOL YEAR 1907-08, at 15 (1908) ("Our graduates are in Harvard, Yale, Princeton, Columbia, and many other institutions, where they have entered without a condition.... About fifty per cent of the graduating class usually goes either to a scientific, classical, law or medical college.").

166. See Richmond, supra note 164 , at 187 (quoting "[a] récent letter from the principal").

167. THIRTY-FIRST ANNUAL REPORT OF THE BOARD OF COMMISSIONERS OF PUBLIC SCHOOLS, TO THE MAYOR AND CITY COUNCIL OF BALTIMORE 84 (Baltimore, Bull \& Tuttle 1860); see also Baltimore Public Schools, supra note 105, at 103 (noting that "the modern foreign languages, with Greek and Latin, are omitted in the female high schools" of Baltimore).

168. MAYES, supra note 126, at 252 (quoting report of President Richard W. Jones to the Board of Trustees (Dec. 1887)).

169. Id. (quoting report of President Richard W. Jones to the Board of Trustees (Dec. 1887)); see also George Duke Humphrey, Public Education for Whites in Mississippi, $3 \mathrm{~J}$. Miss. HisT. 26, 32 (1941) ("During the first fifteen years [of the Mississippi Industrial Institute and College], many of the courses in the college department were on a high school level.").

170. See LAYING OF THE CORNER-STONE OF THE WINTHROP NORMAL AND Industrial COllege of SOUTH CAROLina AT Rock Hill, S.C. MAY 12, 1894 THE EIGHTY-FIFTH BIRTHDAY OF HON. ROBERT C. WINTHROP. 14 (Lancaster, Enterprise Publishing Co. n.d.). 
white women in South Carolina, ${ }^{171}$ echoed these sentiments in 1894. As he assured the audience at the ceremony for laying Winthrop's cornerstone, "'[w]oman's special province in life is that of a homemaker." "172 "'It is to fit women to be mothers-high, noble, properlytrained mothers, the natural and proper guardians of children, that this school is founded."m73 The : school would "'never send forth or harbor one of these 'horrid' creatures," 174 the "'strong minded, bold, brazen, pert, self-asserting female, prating of 'woman's rights,' 'man's tyranny and selfishness,' the 'degradation of nursing children,' and so on, ad nauseam."'175

These same structuring principles were visible in women's public schools outside the South as well. For instance, at the Wadleigh High School for Girls, a public school in New York City, ${ }^{176}$ students had no opportunity to take classes in Latin or Greek, often crucial for college admission in the period. But pupils were required to take two years each of "[d]omestic science and domestic art," and one year each of "'household arithmetic," "hygiene and sanitation, household management, 'social efficiency,' and 'essentials of conduct."' 177 At the Lucy L. Flower Technical High School, a public women's school in Chicago, ${ }^{178}$ "[t]he two years of required study of the arts of homemaking ... rest[ed] upon belief in the imperative necessity of training girls for the profession of homemaker."179 The principal of the William Penn High School, a public women's school in Philadelphia, ${ }^{180}$ was similarly convinced that "[t]he most fundamental of all functions of woman is that of motherhood. But the instincts that make her play house, tend dolls, and sacrifice for her children need to be educated and trained before she can do her best in the bearing and rearing of the race." 181

171. See supra note 117.

172. LAYING OF THE CORNER-STONE OF THE WINTHROP NORMAL AND INDUSTRIAL COllege of South CAROLINA AT ROCK HILL, S.C. MAY 12, 1894 THE EIGHTY-FifTH BIRTHDAY OF HON. ROBERT C. WINTHROP, supra note 170, at 26 (quoting introductory address of Governor Tillman).

173. Id. (quoting introductory address of Governor Tillman).

174. $I d$. at 28 (quoting introductory address of Governor Tillman).

175. Id. at 27 (quoting introductory address of Governor Tillman).

176. See Modern Ideas Followed in Building New High School, N.Y. TIMES, Mar. 1, 1903, at 28, 28; R.K., Old School: Famous, Infamous and Now a Landmark, N.Y. TIMES, July $31,1994,813$, at 6,6 .

177. BENJAMIN R. ANDrews, U.S. BUREau of Education, Bull. No. 37 , EDUCATION FOR THE HOME 96 (1914).

178. See Wells, supra note 164 , at 611 .

179. Id. at 614 .

180. See 21 The EnCyclopedia BritanniCa: A Dictionary of ARTs, SCiEnces, LITERATURE AND GENERAL INFORMATION 369-70 (11th ed. 1911).

181. WILlIAM D LEWIS, DEMOCRACY'S HIGH SCHOQL 68 (Henry Suzzallo ed., 1914). 
Of course, it was not the case that employers in this era were anxious to hire women for a wide array of remunerative and rewarding occupations, or that society in general was eager to smooth women's path to securing economic and political power. But there is a persistent tendency in legal and popular discourse, evident in some of the modern jurisprudence on sex-segregated public education and visible in many other arenas as well, ${ }^{182}$ to explain the positions that women have occupied as the products purely of custom and tradition, long agreed to by women and men alike. Yet it was not simply custom and social expectations that functioned to confine women to relatively few life paths. Women's public schools, created and run by states, localities, and laws, pushed women toward a narrowly defined set of roles, without providing them with the resources and tools that they needed to pursue other paths. These schools helped to create expectations about women's life choices and possibilities, to enforce them, and to make their consequences more powerful and important.

The customs and expectations about women's roles that did exist, moreover, were hardly uncontested. Public jurisdictions in the nineteenth and twentieth centuries prevented women from entering men's public schools, in the face of women's determined efforts to win admission. Indeed, women's exclusion from many of the public schools that prepared men for privileged participation in political and economic life was probably at least as important a factor in maintaining the disabling effects of sex-segregated public education for women, as any feature of the women's public schools.

This exclusion inflicted injuries on women that were both dignitary and material: The men's public schools repeatedly declared that women were unsuited for professional and political success and never would or should attain it, and simultaneously denied women the resources required to pursue such opportunities. In 1858, for instance, a group of women attempted to gain admission to the University of Michigan, the most prominent public university in the Midwest. ${ }^{183}$ The

182. See supra notes $50-54$ and accompanying text.

183. In March of 1858, Sarah Burger notified the University of Michigan's Board of Regents that she and eleven other women would be applying for admission in the coming June. See UNIVERSITY OF MiCHIGAN, REGENTS' PROCEEDINGS WITH APPENDIXES AND INDEX, 1837-1864, at 732 (1915) (Mar. 25, 1858) ("A communication was received from Miss Sarah E. Burger stating that a class of 12 young ladies would present themselves for admission as students in the University in June next. Laid on the table."); 3 HISTORY OF WOMAN SUFFRAGE 526-27 (Elizabeth Cady Stanton et al. eds., Ayer Co. 1985) (1886). Burger, a young secondary school student living in Ann Arbor, had organized this group after a woman's rights convention left her convinced "that the Michigan University as well as all others, should be opened to girls, and that women themselves should first move in the matter." Id. at 527 (quoting Sarah Burger). Burger and her allies promptly applied for admission in June. See UNIVERSITY OF MICHIGAN, supra, at 743 (June 22, 1858) ("A communication was received from Miss S.J. Burger and Miss H.A. Patton of Ann Arbor, asking for admission to the University. A similar request was received from Miss. A.J. Chapin, of Lansing."). 
school rejected the women's applications, ${ }^{184}$ stressing the broad consensus it had found among leading male educators

That an University contemplates the education of candidates for professional and public life, which is not the end of female education. That a different end requires different means; that the effects of such a system upon young ladies would probably be to give them false ideas of life in general and of their particular sphere, than which nothing could be more injurious in the forming stage of character. That young men would be likely to lose in a corresponding ratio in proper sense of the dignity of their own pursuits. ${ }^{185}$

Similarly, a group of women in the 1910s campaigned for the establishment of a white women's coordinate college at the University of Virginia, the leading public university in the South. ${ }^{186}$ This college would not have operated coeducational classes or educational programs ${ }^{187}$ which the University of Virginia had rejected vehemently in the past, ${ }^{188}$ but it would have given white women access to the flagship

\section{Specifically, the Michigan Regents}

Resolved, That to adapt the University to the education of both sexes would require such a revolution in the management and conduct of the Institution that we think it wiser, under all the circumstances both in respect to the interests of the University and the interests of the young ladies, that their application should not be granted and that at present it is inexpedient to introduce this change into the Institution.

UNIVERSITY OF MICHIGAN, supra note 183, at 759 (Sept. 29, 1858).

185. Id. at 788 (Report on the Admission of Females, Submitted September 29, 1858).

186. Mary-Cooke Branch Munford organized the first systematic campaign to win white women's admission to the University of Virginia in 1910, establishing the "Coördinate College League" and recruiting a dedicated core of volunteers. See, e.g., Letter from MaryCooke Branch Munford, Coördinate College League, to E.A. Alderman, University of Virginia 1 (Dec. 15, 1915) (on file with author; Alderman Library, University of Virginia); WALTER RUSSELl Bowie, SUNRISE IN THE SOUTH: THE LIFE OF MARY-COOKE BRANCH MUNFORD 107 (1942).

187. The very word "'co-education," "'next to Woman's Suffrage," was enough, a prominent member of the Coördinate College League once explained, to leave Virginia's legislators "'scared ... to death."' BowIE, supra note 186, at 140 (quoting Letter from Mrs. Norman Randolph to Mary-Cooke Branch Munford (1914)).

188. In 1894, for instance, the Virginia faculty and the university's Board of Visitors emphatically rebuffed a faculty committee's recommendation that the school accept female students on the same terms as men. See 13 University of Virginia, Minutes of the Faculty 384,386 (May 12, 1894) (on file with author; Alderman Library, University of Virginia); 6 University of Virginia, Minutes of the Rector and Board of Visitors 379-81 (June 11, 1894) (on file with author; Alderman Library, University of Virginia). The faculty members who supported women's exclusion predicted that admitting female students to the University of Virginia would undermine "[t] he exalted position which matrons and daughters have long held and still hold in our social organization," explaining that "[t]he scheme of coeducation strikes at the very root of this prized form of society, and tends to subvert what we cherish as most excellent in our homes." 13 University of Virginia, Minutes of the Faculty 417 (June 4, 1894) (on file with author; Alderman Library, University of Virginia). Women who attended the University of Virginia would, they warned, "become familiar, boisterous, bold in manners, often rudely aggressive, and ambitiously competitive with men, thus producing, in general, a type of womanhood from which we devoutly pray to be spared." Id. at 416. 
university's faculty, library, laboratories, and other resources. ${ }^{189}$ The Virginia legislature, however, refused to open even a coordinate college for white women at the University of Virginia. ${ }^{190}$ As one male activist against the coordinate college explained, "higher education unfits [woman] for domestic employment."191 Admitting women to the University of Virginia, another man similarly warned, would be "quite tragical," for it would lead women to "imagine that they will be permanently superior to the callow class mates surpassed by them in college; and so plan lives tending to independence of and competition with men."192

Historical accounts of the rise of coeducation in public education often envision coeducation as an important break from the patterns established in sex-segregated education. ${ }^{193}$ Yet the two forms of public

189. See, e.g., Mary C.B. Munford \& Virginia S. McKenney, A Plea for Co-Ordination, 7 ALUMNI BULL. U. VA. 4, 6-7, 9 (1914). The League's arguments in favor of its plan were accordingly able to stress its relative moderation. Indeed, the League very deliberately attempted to win allies among the many powerful opponents of coeducation in Virginia by characterizing the coordinate college as a less radical means of diffusing women's protests. "[C]o-education," the League warned, "will be inevitable, unless Virginia women are given opportunities absolutely equal to those afforded Virginia men." CO-ORDINATE COLLEGE

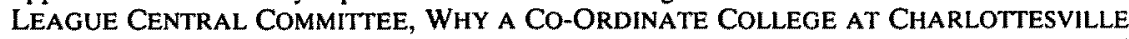
AFFILIATED WITH THE UNIVERSITY OF VIRGINIA RATHER THAN A SEPARATE COLLEGE 6 (n.d.).

190. Munford and her League had the support and the political skills needed to prod the legislature, which met every other year, into considering their proposal at five consecutive sessions starting in 1910. See Almost a Victory, HARPER's WKLY., Apr. 11, 1914, at 5, 5; CoOrdinate Bill Wins in Senate by Big Majority, TIMES DiSPATCH (Richmond), Mar. 11, 1914, at 1, 1; Orie Latham Hatcher, The Virginia Man and the New Era for Women, 106 NATION 650, 651 (1918); House Postpones College Measure, TIMES DisPaTCH (Richmond), Jan. 21, 1912, at 1, 1; House Rejects Woman's College Bill, 48 to 46, RICHMOND TIMES-DiSPATCH, Mar. 8, 1916, at 1, 1; Lewis $\mathrm{H}$. Machen, The Woman's College, Times DisPatcH (Richmond), Jan. 21, 1912, at 4, 4. But they lacked the political power, and the legal rights, necessary to win their campaign. In 1916, the League came as close to victory as it ever would. The Virginia Senate passed a bill that year to establish a coordinate college, which failed in the Virginia House by only two votes. See JOURNAL OF THE HOUSE OF Delegates of Virginia, Session Which COMMENCEd at THE State CaPITOL ON WEDNESDAY, JANUARY 12, 1916, at 947-48 (1916) (Mar. 7, 1916); House Rejects Woman's College Bill, 48 to 46, supra, at 1; Open Letter from Mary-Cooke Branch Munford, Chairman Central Committee, Coördinate College League 1 (Mar. 14, 1916) (on file with author; Alderman Library, University of Virginia).

191. Edwin F. Surber, The Education of Women, TIMES DiSPATCH (Richmond), Jan. 16, 1914, at 4, 4 .

192. Letter from Arthur Lefrin to J.M. Page, University of Virginia 2 (Aug. 14, 1914) (on file with author; Alderman Library, University of Virginia).

193. Carl Degler, for instance, stresses what he calls "the decision to include girls in primary and secondary schooling on a par with boys." Carl N. Degler, What the Women's Movement Has Done to American History, in A FEMINIST PERSPECTIVE IN THE ACADEMY: THE DIFFERENCE IT MAKES 67, 74 (Elizabeth Langland \& Walter Gove eds., 1981). Similarly, Thomas Woody's classic history of women's education explains that:

Any wide acceptance of coeducation in practice had obviously to wait upon more general approval of the idea that girls should have more than rudimentary education. Hence the first academies and high schools, insofar as they promoted the educational interests of women, had to do it on the separate plan. The high schools once under $498 y_{3}$ soon changed, however, 
schooling were much closer in function and effect than one might initially suppose and has frequently been assumed. Coeducation became the dominant form of public education in the United States by the late nineteenth century, but not because most public jurisdictions were committed to providing women with the same life choices, prospects, and possibilities open to men. To the contrary, the decisionmakers and advocates behind coeducational public schools were often explicitly determined to maintain and enforce sex roles that confined women to marriage and motherhood and directed men to economic and political success.

The practicalities of organizing a status regime can affect how it develops and can cause it to change in form. Segregating public institutions is necessarily an expensive proposition, unless jurisdictions are willing to exclude one group completely. ${ }^{194}$ In this case, the cost of sex-

and became chiefly coeducational. They benefitted by the great faith in girls' education that was gradually built up by the seminaries from the middle of the eighteenth to the middle of the nineteenth centuries. Believing in equal education for their sons and daughters, communities began to seek an institution to offer it.

2 THOMAS WOODY, A HISTORY OF WOMEN'S EDUCATION IN THE UNITED STATES 228 (1929); see also HELEN LEFKOWITZ HOROWITZ, ALMA MATER: DESIGN AND EXPERIENCE IN THE WOMEN'S COLLEGES FROM THEIR NINETEENTH-CENTURY BEGINNINGS TO THE 1930 , at $85-86$ (1984) ("As one of the early women graduates of the University of Michigan..., Alice Freeman had experienced the unique independence of that pioneer coeducational university. In the first years of coeducation, the university allowed women the complete freedom of men, letting them attend all classes (except in the Medical College) and live in boarding houses without supervision."). For an example of the influence of this historical view in the legal literature, see Morgan, supra note 80 , at 386 ("[B]y the 1890 s it was widely accepted that schools should offer essentially the same curriculum to both boys and girls and educate children of both sexes together.").

194. Some historians, for example, have suggested that southern states in the late nineteenth century may have passed laws requiring racial segregation in public transportation in part because they recognized that railroad lines, steamboat operators, and other common carriers were not consistently willing to bear the expense of providing wholly separate accommodations for whites and blacks unless compelled to do so by legislation. See Welke, supra note 131, at 266-67 ("[Case] law and their own financial interest led carriers to allow respectable women of color to ride in first-class ladies' accommodations. By the late $1880 \mathrm{~s}$ and early 1890 s it had become clear that the wall guarding Southern white woman's sacred place-and hence white supremacy - was not secure in the hands of carriers and courts. Southern state legislatures quickly moved to impose absolute racial separation first on railroads and then on other carriers not only to control the region's black population, but also to force common carriers and Southern courts into line."); $i d$. at 312 ("Those in power in the South adopted statutory Jim Crow beginning in the 1890 s because ... [inter alia] carriers in allowing respectable black women to ride in first-class ladies' accommodations were themselves failing to protect the purity of white womanhood. Seen in this light, the shift to statutory Jim Crow not only was necessary to control Southern blacks, but also to force common carriers ... into line.").

In the first half of the twentieth century, the National Association for the Advancement of Colored People (NAACP) recognized that southern states and localities were able to afford racially segregated public institutions only because they spent so few resources on the schools and other public facilities for African-Americans. One early strategy that the NAACP devised was to bankrupt these southern jurisdictions through litigation that actually forced them to comply with rigorous separate but equal standards in their segregated institutions. See Mark V. TUSHNET, MAKing Civil Rights Law: Thurgood Marshall and THE SUPREME COURT, 1936-1961, at 12-13 (1994); see also id. at 117 ("In 1941 the United 
segregated schooling importantly drove the rise of public coeducation. For jurisdictions, like those in the South and Northeast, intent on using sex segregation in public education as an expression of racial or economic privilege, as well as gender status, sex segregation represented money well spent. ${ }^{195}$ But for states, cities, and towns not as interested in reinforcing race or class divides in their public educational systems, sex segregation was often too expensive and too elaborate an expression of gender norms. ${ }^{196}$ These jurisdictions could easily structure their coeducational schools to maintain men's and women's status in virtually the same way that sex-segregated public institutions did, without having to bear the cost of complete sex segregation.

Like their single-sex counterparts, coeducational public schools employed a number of different mechanisms. Sometimes, coeducational public schools formally segregated a portion of their classes or programs along sex lines as a way of directing students to life paths associated with their sex (or their sex and race) and keeping them from resources and opportunities that might have made deviation more

States Office of Education reported that it would cost the South about $\$ 26$ million a year to equalize teachers' salaries, and another $\$ 9$ million to equalize student-teacher ratios in black and white schools.").

195. Many state universities south of the Mason-Dixon line and east of the Mississippi River were sex-segregated in this period. In 1907, for example, only the Universities of Alabama, Kentucky, Mississippi, North Carolina, Tennessee and West Virginia admitted both men and women. See Charles R. Van Hise, Educational Tendencies in State Universities, 34 EDUC. REV. 504, 511 (1907). A federal survey conducted in 1882 found that 19 out of 196 cities and large towns were operating sex-segregated public schools. See U.S. BUREAU oF EDUCATION, CiRCULAR OF INFORMATION No. 2-1883, COEDUCATION OF THE SEXES IN THE PUBLIC SCHOOLS OF THE UNITED STATES 12 (Washington, Government Printing Office 1883). The nineteen jurisdictions were heavily concentrated in the South and Northeast: Mobile, Alabama; Wilmington, Delaware; Macon, Georgia; Belleville, Illinois; New Orleans, Louisiana; Baltimore, Maryland; Marblehead, Massachusetts; Newburyport, Massachusetts; Vicksburg, Mississippi; New Brunswick, New Jersey; Brooklyn, New York; Allentown, Pennsylvania; Easton, Pennsylvania; Harrisburg, Pennsylvania; York, Pennsylvania; Charleston, South Carolina; Knoxville, Tennessee; Austin, Texas; and Alexandria, Virginia. See id. at 24; see also Richmond, supra note 164, at 185 ("In 1914, according to the Commissioner's report, there were 28 of these [public women's high] schools, which were distributed as follows: Massachusetts, 4; New York, 4; Pennsylvania, 5; Maryland, 4; South Carolina, 1; Georgia, 4; Louisiana, 2; Kentucky, 1; Illinois, 1; and California, 2. The total number of girls in these schools was 34,362. The two States of New York and Pennsylvania have over 60 per cent. of the entire number, while if we include Massachusetts and Maryland the four have over 80 per cent.").

196. The economic motivations behind admitting women to schools with men are easiest to see in the public universities of the Midwest, where the traditions of sex segregation were less entrenched than in the East or South but still stronger than in the developing West. As the University of Wisconsin's president later explained, "[t]he western states in these early days were too poor to support two high-grade educational institutions." Van Hise, supra note 195 , at 509 . There was no way to provide women with access to public higher education "but to adopt coeducation, and this was the solution which was gradually forced upon the older state universities of the middle west." Id. If nothing else, one president of the University of lowa also reasoned, "then one strong plea may be made for coeducational colleges on the score of economy. Duplication of all essential equipments ... can hardly be justified." J.L. Pickard, Coeducation in Colleges, 13 EDuC. 259, 265-66 (1893). 
possible. In the early twentieth century, for instance, the University of California at Berkeley barred female students from admission to Phi Beta Kappa, the most prestigious academic honor society, reasoning that "'when it came to finding a good job, men needed the help of this honor more than women did." "197 With a similar division of life roles in mind, Marinette, Wisconsin's coeducational public high school began segregating its classes in physics and chemistry by sex in 1912. As the superintendent of the city's schools explained, the physics and chemistry classes limited to male students were "technical and mathematical" and "scientific," deliberately designed to prepare men for "scientific and engineering courses in the colleges and universities" and careers "'in the arts and industries." In contrast, "“[t]he course in physics given to the girls' classes [was] largely informational and cultural and less technical." The only chemistry classes open to female students, in turn, were "'built up largely around the chemistry of the home, of cooking, food values, and adulterations and their detection." "198

197. Lillian Moller Gilbreth, in THERE WAS LIGHT: AuTOBIOgRAPHY OF A UNIVERSITY, BERKELEY: 1868-1968, at 83, 84-85 (Irving Stone ed., 1970); see also id. at 449 (providing biographical information about Gilbreth). In 1916, Oscar M. Voorhees, the secretary of Phi Beta Kappa's National Council, proposed altering the organization's rules to make it more difficult for female college students to gain admission. As he explained, election to Phi Beta Kappa was determined "on the basis of grades only." Oscar M. Voorhees, Proceedings of the Twelfth National Council, 3 PHI BETA KAPPA KEY 8, 20 (1916). Under this system, however, "the number of undergraduate women elected nearly equaled the number of men," and "[m]any chapters elect[ed] each year more women than men." Id. Voorhees was concerned that "some of our chapters" did not have "the highest reputation by reason of the preponderance of women," and concluded that "election on the basis of grades only has ... been pushed to the extreme." Id. As he reasoned, "[t]he way must be kept open to the men, and promising students be encouraged to seek membership. In my opinion there are other marks in undergraduates of the promise of usefulness than mere grades." $/ d$. Phi Beta Kappa's president quickly appointed a committee to study the matter. See id. at 33-34.

198. U.S. Bureau of Education, Bull. No. 31, Special Features in City SCHOOL SYSTEMS 52 (1913) (quoting G.H. Landgraf, superintendent of city schools). The Broadway High School in Seattle, Washington also segregated some of its science classes by sex, along with some of its classes in English, math, history, Latin, French, Spanish, German, commercial work, and manual training. See Thomas R. Cole, Segregation at the Broadway High School, Seatlle, 23 SCH. REv. 550, 551 tbl.I (1915). One teacher, who approved of the arrangement, explained its advantages this way in 1915:

In physics, I have been able to leave out much of the most difficult part for the girls and do more extensive work in the parts in which they are naturally most interested. The work of the boys has been made to include a great deal that I have never found time to touch in mixed classes. I would say that boys have done 30 to 40 per cent more work than in mixed classes. The brighter girls have probably lost the fund of outside information, applications, etc., that the boys contribute to the recitation.

Id. at 553; see also Richmond, supra note 164, at 187 (reporting in 1916 that sex-segregated classes operated in coeducational public schools "in Seattle, Washington; in Fresno, California; in Muskogee, Oklahoma; in Richmond, Indiana; the Englewood High School, in Chicago; the high schools in Columbus, Ohio, and in Hackensack, New Jersey, the Junior High School in Clinton, Iowa" and noting that "[o]f these 8 schools, 4 separate the classes in science; 3 in physiology, physical culture, and manual training, either through all or a part of the course; 2 separate in drawing"). 
Sex-segregated home economics classes in coeducational public schools were also particularly notable for pushing female students toward home and family, while simultaneously reflecting a particular determination to train black women for domestic service. The public school system in Long Beach, California, for instance, began requiring all female high school students in 1927 to take "a course in home management" that featured the "Study of the job of homemaking as a vocation for women." 199 A 1929 study of public high schools in eleven southern states found that thirty percent of the surveyed schools required female students to enroll in home economics courses. ${ }^{200} \mathrm{~A}$ survey of the black public high schools operating in ten southern states during the 1930-1931 school year found that as many as eighty-five percent of them had required home economics classes for female students. ${ }^{201}$

Often, however, coeducational public schools did not officially limit a class or program to students of one sex, but utilized a variety of other means that were approximately as effective at steering female students toward some courses, opportunities, and life paths, and away from others. For instance, one strategy that many coeducational public colleges and universities employed was to establish home economics departments. By 1905, thirty-six of the land-grant colleges, practically every one in the North and West, had such a department. ${ }^{202}$ These de-

199. Maud E. Hayes et al., Budgets in a Home Management Course for a Senior High School, 20 J. HOME ECON. 75, $75-76$ (1928); see also MARION TALBOT, THE EDUCATION OF WOMEN 152-53 (1910) ("II]n the Chicago Public Schools in December, 1909... . [a]ll girls in the elementary schools have either domestic science or domestic arts as a requirement for graduation.").

200. See Rosaline Ivey, Status of Home Economics in Certain Southern Accredited High Schools 3-6, 23 (1929) (unpublished M.A. thesis, George Peabody College for Teachers) (on file with author).

201. See Ruth Aline Patton, A Study of Home Economics in Some Negro High Schools 5-7, 26-27, 55 (1931) (unpublished M.A. thesis, George Peabody College for Teachers) (on file with author); see also TWENTY-FIFTH ANNUAL REPORT OF THE COMMISSIONER OF LABOR, 1910: INDUSTRIAL EDUCATION 131-33 (1911) ("[At the Armstrong Manual Training School, a public high school for African-American students in Washington, D.C.,] the boys uniformly [take] woodwork ... in the first year and forging in the second year. The girls do plain sewing and dressmaking in the first year and dressmaking only in the second year... The laundry department prepares the girls to do scientific laundry work, while the course in domestic science fits them for domestic service as well as for home duties. It is said that a number of the girls go into domestic service upon graduation."); Kate Brew Vaughn, Some Colored Schools of the South, 8 J. HoME ECON. 588, 588 (1916) ("Eight years ago, upon taking charge of a student body that seemed interested rather superficially in the subjects of study, ['[t]he principal of colored schools at Winston-Salem'] decided to open a kitchen, a sewing room, and a laundry to fit the girls and boys for employment. A few boys, and fewer girls, applied. He then required every girl to enter the classes, but the sewing classes were filled and cooking and laundry classes went begging. The School Board finally decreed that every girl who failed to give the required amount of time to cooking, sewing, and laundry, would be dismissed.").

202. See ISABEL BEVIER, HOME ECONOMICS IN EDUCATION 128 (1924); see also id. ("The proceedings of the Association of Land-Grant Colleges for 1922 includes a list of forty-one such colleges with departments of home economics."). 
partments were usually not formally sex-segregated, but they were deliberately designed to direct female students toward marriage and maternity and away from the courses that male students attended and the professional preparation offered there.

Consider the University of Wisconsin, for example. This school became formally coeducational in $1874 .^{203}$ But as the president of the university, Charles Van Hise, proudly explained in a 1907 address, the school had nonetheless managed to orchestrate "nearly complete segregation on a large scale by the establishment of courses and colleges which are practically for the one sex or the other." 204 In particular, "[t]he colleges of engineering, law, commerce, agriculture, and medicine" were "essentially men's colleges," although officially "open to women." ${ }^{205}$ To help accomplish this, the University of Wisconsin, like the universities of Illinois, Kansas, Minnesota, Nebraska, Ohio, Tennessee, and many other states, had established "for the women" "courses for training the heads of households," "[w] hether such courses be called home economics, household science, or domestic science."206 The director of the Department of Home Economics at the University of Illinois from 1900 to 1921 similarly reported that her department was designed to guide women away from opportunities that they might have been tempted to pursue outside the home, "lured by the promise of greater freedom and larger compensation."207

When coeducational schools were not steering their female students toward marriage itself, they structured their course offerings to direct women to a small number of female-dominated jobs familiar from the curricula of many women's public schools. One 1914 survey, for instance, found that the high schools in 147 cities offered the following classes, clearly intended to occupy female students: "Cooking,

203. See 3 University of Wisconsin, Series No. 1/1/1, Board of Regents Minutes 201-02 (Jan. 21, 1874) (on file with author; University of Wisconsin-Madison Archives) ("[T]he University shall be open to female as well as male students, with no other regulations or restriction on the part of the Board of Regents, than those that may be deemed necessary and proper for the preservation of order and discipline.").

204. Van Hise, supra note 195, at 516.

205. Id.

206. Id. at 516-17. Edwin E. Slosson similarly contended that coeducational schools like the University of Wisconsin should promote what he called "natural segregation," by "providing vocational courses which [will] draw women away from the liberal arts department as the engineering courses have drawn off the men." Edwin E. Slosson, University of Wisconsin, 67 INDEP. 8, 22 (1909). "[I]t is clear," Slosson explained, "that the main business of most women is in household administration and industries." Id.

207. Bevier, supra note 202, at 221. Lou C. Allen, the first Professor of Domestic Science at the University of Illinois, see id. at 124-25, described the school's home economics department this way: "The school was the outgrowth of a conviction that a rational system for the higher and better education of women must recognize their distinctive duties as women-the mothers, housekeepers, and health keepers of the world-and furnish instruction which shall fit them to meet these duties." Id. at 126 (quoting Allen). 
98; dressmaking, 92; sewing, 89; home economics, 72; millinery, 71; nursing, 24; costume designing, 4; dietetics, 1; food preparation, 1; house decoration, 1; laundering, 1."208

Yet another strategy, less common but motivated by similar concerns, was to establish junior colleges in an effort to keep female students away from flagship coeducational public universities and the prestige and professional advancement offered there. For example, Benjamin Ide Wheeler, the president of the University of California from 1899 to $1919,{ }^{209}$ advised his female students that they were at school "for the preparation of marriage and motherhood. This education should tend to make you more serviceable as wives and mothers." ${ }^{210}$ But Wheeler still sought to minimize female enrollment at the University of California, and accordingly supported the establishment of junior colleges in the state on the ground that women were "more likely [than men] to remain at home and attend the junior college."211

In sum, the historical record reveals that separation is not the only mechanism through which unequal citizenship can be maintained and inferiority enforced. Historically, role confinement has been evident in approximately equal measure in sex-segregated and coeducational public schools. This suggests that a Court deciding whether sexsegregated public education is inherently incompatible with women's equality could usefully consider whether sex-segregated public schools actually deny women "full citizenship stature" and "create or perpetuate the legal, social, and economic inferiority of women" in a way or to a degree that coeducational public schools do not. ${ }^{212}$ It also suggests that if sex-segregated public education is not completely banned under Virginia's framework, a Court determining how best to regulate single-sex public schools so that they do not infringe upon women's equal status would be well-advised to pay attention to the potential problem of role confinement. Along the same lines, a Court seeking to effectively safeguard women's citizenship could wisely focus much more constitutional scrutiny on coeducational public schools directly,

208. Richmond, supra note 164 , at $195-96$.

209. See William Warren Ferrier, Origin and Development of the UNIVERSITY OF CALIFORNIA 408-09, 511-13 (1930).

210. President Addresses the Women Students, DaILY CALIFORNIAN, Sept. 1, 1904, at 1, 1. In 1900, a group of female students at the University of California had articulated a somewhat different account of the purpose of their education. As they explained, "[w]e come to study, to learn, to enjoy, to meet the nicest men, to take a degree and to go forth prepared for work, in or out of the home, as Providence decrees." What We Can Do, 39 OCCIDENT 233, 233-34 (1900).

211. Benjamin Ide Wheeler, Report of the President of the University, in UNIVERSITY OF CALIFORNIA, BIENNIAL REPORT OF THE PRESIDENT OF THE UNIVERSITY ON BEHALF OF THE REgENTS TO His EXCELLENCY THE GOVERNOR OF THE STATE, 1910-1912, at 5, 5 (1912). 
considering the possibility that these schools may also need more stringent constitutional regulation to prevent them from impinging upon women's equality.

\section{Women and Men Are Not Necessarily Interchangeable in Considering What Denies "Full Citizenship" and Maintains}

\section{"Inferiority"}

Lastly, the historical record of sex-segregated public education reveals that women and men are not necessarily interchangeable in considering whether a practice denies "full citizenship" and maintains "inferiority."213 Virginia seems to express a particular constitutional concern for women's "full citizenship stature" and "the legal, social, and economic inferiority of women." 214 This specific focus on women appears both in the opinion's language ${ }^{215}$ and in the justification that Virginia offers for its suggested standard: If constitutional law has a responsibility to safeguard and defend women's equal citizenship because of the law's longstanding role in maintaining and enforcing women's inequality, ${ }^{216}$ no historical record would provide the same justification for committing the sex discrimination jurisprudence to the protection of men's equal citizenship. At the same time, there are portions of the Virginia opinion that appear to treat men and women interchangeably. Virginia, for instance, makes clear that sex-segregated public schools must, at a minimum, conform to separate but equal requirements. Its application of these requirements to the Virginia Military Institute, which excluded women, is not noticeably different from the Hogan Court's application of separate but equal principles to the Mississippi University for Women, which excluded men. ${ }^{217} \mathrm{Cer}$ tainly, the sex discrimination jurisprudence before Virginia treats the constitutional claims of men and women interchangeably. Indeed, the Court has stressed that point by choosing cases with male plaintiffs for its announcement of heightened scrutiny (Craig), and its first opinion on sex-segregated public education (Hogan). ${ }^{218}$

The historical record of sex-segregated public education; however, reveals that what deprives women of equal citizenship may not necessarily do the same for men. This is one reason, for instance, that compliance with separate but equal standards (which, as we have seen,

213. $I d$.

214. Id. (emphasis added).

215. See supra text accompanying note 80 .

216. See supra note 77 and accompanying text.

217. See supra notes $49,65-73$ and accompanying text.

218. See supra text accompanying notes 18-20, 47-49, 52-60. 
may not always be sufficient to protect women's equal status) ${ }^{219}$ also may not always be needed to safeguard "full citizenship stature" or combat "legal, social, and economic inferiority." 220 Historically, public school systems have frequently caused women both material and dignitary harm by denying them access to the opportunities and resources available in men's public schools. ${ }^{221}$ But it is not at all clear that men's exclusion from women's public schools (where men had no access to the same opportunities and curricula elsewhere) has historically operated to deprive either men or women of "full citizenship stature."222 This does not tell us whether any particular modern arrangement of sex-segregated public education that does not meet separate but equal standards is still consistent with the "full citizenship stature" of women (or men). ${ }^{223}$ But it does suggest that the importance to be placed on compliance with separate but equal standards is something that could be the subject of particularized investigation rather than assumptioneven if the Court's firm commitment to separate but equal principles. as a required constitutional minimum indicates that it is unlikely to do this. More generally, this record suggests that a Court considering whether, when, why, and how a practice denies equal citizenship should not simply assume that the answer will be the same for women and men.

\section{CONCLUSION}

Virginia suggests that the constitutional law of sex discrimination should focus on whether a practice denies women "full citizenship. stature" or "create[s] or perpetuate[s] the legal, social, and economic inferiority of women." 224 But the opinion does not tell us how to determine which practices meet those criteria. The answer to this question is hardly obvious or automatic. As this Article's case study of sexsegregated public education suggests, however, a historical record can usefully inform an inquiry into whether, when, why, and how a particular practice is consistent with women's equal status. Ultimately, this project of specific application may be at least as important as any more general constitutional commitment to protecting women's "full citizenship stature" and combating their "legal, social, and economic

219. See supra text accompanying note 156 .

220. United States v. Virginia, 518 U.S. 515, 532, 534 (1996).

221. See supra text accompanying notes 98-102, 183-192.

222. Virginia, 518 U.S. at 532.

223. Id.

224. Id. at 532,534 
inferiority." 225 Indeed, it may call into question many of the core assumptions of the current sex discrimination jurisprudence. 